\title{
An Improved Taxonomy of Creativity Measures Based on Salient
}

\section{Task Attributes}

Selina Weiss ${ }^{1 *}$, Oliver Wilhelm ${ }^{1}$, \& Patrick Kyllonen ${ }^{2}$

\footnotetext{
${ }^{1}$ Department of Individual Differences and Psychological Assessment, Institute for Psychology and Education, Ulm University, Ulm, Baden-Wuerttemberg, Germany

${ }^{2}$ Division of Research and Development, Educational Testing Service, ETS, Princeton, New Jersey, United States of America

* Corresponding author
}

(C) 2021, American Psychological Association. This paper is not the copy of record and may not exactly replicate the final, authoritative version of the article. Please do not copy or cite without authors' permission. The final article will be available, upon publication, via its DOI: $10.1037 /$ aca0000434

Author Note:

Correspondence concerning this article should be addressed to Selina Weiss, Institute for Psychology and Pedagogy, Ulm University, Albert-Einstein Allee 47, 89081 Ulm, Germany. Telephone: +49-(0)731/50 31145. Fax: +49-(0)731/50 31149. Email:

\section{selina.weiss@uni-ulm.de}

This research was supported was not supported by any grants. We thank the research assistants who helped coding the measures. For all measures, we have reported example items, besides we report data exclusion criteria. The sample items along with the human ratings are available in the OSF https://osf .io/e49n3/. 


\begin{abstract}
The assessment of creativity presents major challenges. The many competing and complementary ideas on measuring creativity have resulted in a wide diversity of measures, making it difficult for potential users to decide on their appropriateness. Prior research has proposed creativity assessment taxonomies, but we argue that these have shortcomings because they often were not designed to (a) assess the essential assessment features and (b) are insufficiently specified for reliably categorizing extant measures. Based on prior categorization approaches, we propose a new framework for categorizing creativity measures including the following attributes: (a) measurement approach (self-report, other-report, ability tests), (b) construct (e.g., creative interests and attitudes, creative achievements, divergent thinking), (c) data type generated (e.g., questionnaire data vs. accomplishments counts), (d) prototypical scoring method (e.g., consensual assessment technique; CAT), and (e) psychometric problems. We identified 228 creativity measures appearing in the literature since 1900 and classified each measure according to their task attributes by two independent raters (rater agreement Cohen's kappa .83 to 1.00 for construct). We provide a summary of convergent validity evidence and psychometric shortcomings. We conclude with recommendations for using the taxonomy and some psychometric desiderata for future research.
\end{abstract}

Keywords: Creativity; Divergent Thinking; Self-report; Other-report; Taxonomy 
Despite a long history of creativity research and the great interest in understanding and measuring creativity, the question of how best to assess creativity in a psychometrically sound manner remains unsolved (e.g., Barbot et al., 2019; Long et al., 2014; Plucker \& Makel, 2010). This can be attributed to the challenges of defining creativity (e.g., Barron, 1955; Runco \& Jaeger, 2012) and because of its vagueness, the boundaries between creativity and other constructs, such as problem-solving (Weisberg, 1988), openness to experience (Feist, 1998; McCrae, 1987), and general retrieval ability (Forthmann, et al., 2019) appear indistinct. Nevertheless, the assessment of creativity is crucial, when it comes to forwarding our understanding of creativity (e.g., such as in the large-scale comparative assessments of creative thinking in children [PISA 2021; OECD: PISA 2021; Vincent-Lancrin, 2017]).

Before we provide measurement attributes for an improved and exhaustive categorization system, we describe previous categorization attempts in the next paragraphs.

\section{Previous Categorization of Creativity Assessment}

The creativity literature provides several taxonomies for categorizing research and measurement (e.g., Snyder et al., 2019). Extant taxonomies vary widely concerning terminology, as they are often based on different theoretical approaches and serve different purposes. Table 1 summarizes prominent taxonomies and categorization systems presenting the original labels and our attempt to unify terminology (primarily included attributes), which will be further described in the section "Building upon previous taxonomies". 
Table 1

Previous Taxonomies with Topic Coverage

\begin{tabular}{|c|c|c|}
\hline Authors & $\begin{array}{l}\text { Original categorization/taxometric } \\
\text { approach }\end{array}$ & $\begin{array}{l}\text { Primarily } \\
\text { included } \\
\text { attributes }\end{array}$ \\
\hline Rhodes, 1961 & process, product, person, press & \\
\hline Hocevar, 1981 & $\begin{array}{l}\text { ten measurment categories (e.g., divergent } \\
\text { thinking, product judgments) }\end{array}$ & \\
\hline Mumford \& Gustafson, 1988 & $\begin{array}{l}\text { nomological net of creative potential (e.g., } \\
\text { environment, skills/abilities, and } \\
\text { personality) }\end{array}$ & \\
\hline Lubart, 1994 & $\begin{array}{c}\text { eight measurement categories (e.g., peer } \\
\text { reviews) }\end{array}$ & \\
\hline Eysenck, 1996 & $\begin{array}{l}\text { trait (e.g., personality and ability) or } \\
\text { achievement measures }\end{array}$ & $\xi$ \\
\hline Amabile, 1996 & $\begin{array}{l}\text { assessment techniques (e.g., tests, } \\
\text { subjective judgment) }\end{array}$ & \\
\hline Kirschenbaum, 1998 & $\begin{array}{c}\text { nine dimenisions of creative activity (e.g., } \\
\text { interest) }\end{array}$ & $\bigoplus_{-2}$ \\
\hline Mayer, 1999 & $\begin{array}{l}\text { psychometric, psychological, biographical, } \\
\text { biological, computational, contextual }\end{array}$ & \\
\hline Plucker \& Makel, 2010 & process, person, enviroment & \\
\hline Batey, 2012 & $\begin{array}{l}\text { facets (e.g., process, product), } \\
\text { measurement approach (e.g., self-rating), } \\
\text { and level (e.g., individuals) }\end{array}$ & \\
\hline $\begin{array}{l}\text { Long, 2014; Long \& } \\
\text { Plucker, 2015 }\end{array}$ & $\begin{array}{c}\text { case studies, experimental paradigms, and } \\
\text { questionnaire approaches }\end{array}$ & \\
\hline Forgeard \& Kaufman, 2016 & $\begin{array}{l}\text { constructs (e.g., imagination, creativity, } \\
\text { and innovation) }\end{array}$ & \\
\hline Barbot, et al., 2019 & $\begin{array}{l}\text { Divergent thinking, product assessment, } \\
\text { self-reports }\end{array}$ & \\
\hline Benedek et al., 2019 & $\begin{array}{c}\text { task-type (e.g., problem-solving) and } \\
\text { neuroscience method }\end{array}$ & \\
\hline Kaufman, 2019 & focus (e.g, activties, evaluation, process) & \\
\hline Snyder et al., 2019 & $\begin{array}{c}\text { measurement types (e.g., self-, and other } \\
\text { measures) and category (e.g., process, } \\
\text { person) }\end{array}$ & \\
\hline Said-Metwaly, et al., 2019 & process, product, person, press & (1) 帚 $\alpha$ \\
\hline
\end{tabular}

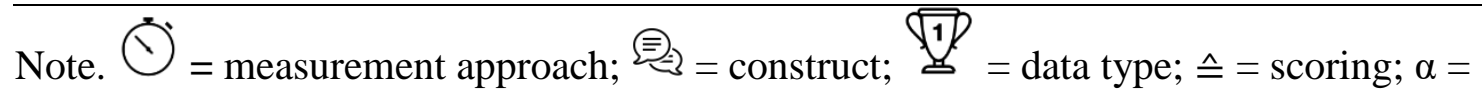
psychometric problems.

One categorization approach — which has been further applied and developed in later taxonomies - describes the process of creativity, the creative product, the creative person, and 
the environment in which creativity arises (4 P's; Rhodes, 1961). This approach to understanding creativity has been further applied and developed as a categorization basis (e.g., Batey, 2012; Plucker \& Makel, 2010; Snyder et al., 2019; Said-Metwaly et al., 2019). A systematic review by Snyder and colleagues (2019) included measures from 1984 to 2013 that were coded by the type of measurement (e.g., self-rating of creativity) and related to the 4 P's. A categorization approach by Batey (2012), includes the 4 P's as facets, next to a categorization by the measurement approach (e.g., self-rating) and the observational unit (e.g., team).

Other taxometric approaches categorized measurements either very broadly by the research purpose (e.g., case-studies: Long, 2014; Long \& Plucker, 2015; biological: Mayer, 1999; neuroscience (interdisciplinarity): Benedek et al., 2019) or describe measurement categories. The description of measurement categories vary in their breadth and overlap. Hocevar (1981) distinguished ten measurement categories (such as divergent thinking, product judgment), while Lubart (1994) used eight such categories (including peer-reports, divergent thinking) and Barbot (2019) classify indicators as divergent thinking, product assessment, and self-reports. Divergent thinking tasks are particularly prominent in the literature and appear in many taxonomies_-either described as measurement approach, construct or even data type (e.g., Batey, 2012; Barbot, et al., 2019; Plucker \& Makel, 2010). Besides the measurement type, other research focusses on the measurement content describing, for example, different dimensions of creative activities (e.g., Kirschenbaum, 1998), different constructs (imagination, creativity, and innovation; Forgeard \& Kaufman, 2016), or different foci (e.g., activities; Kaufman, 2019). Other prominent approaches focus on the assessment technique (e.g., product assessment; Amabile, 1996), data distributions (Eysenck, 1996), and nomological net (Mumford \& Gustafson, 1988).

\section{Building upon Prior Categorizations}


Previous categorizations are difficult to reconcile because they are based on different terminology and were originally intended to address creativity assessment from specific angles and foci. However, these approaches are of great value, when it comes to the development of an overarching categorization approach. Besides, they can help to identify previously used terminologies in the fields and to harmonize prospective usage. For example, the content measured in creativity tests has been described as constructs (Forgeard \& Kaufman, 2016), focus (Kaufman, 2019), creative-activity (Kirschenbaum, 1998), or facet (Batey, 2012). Building upon prior categorizations we have identified the following task attributes: 1) measurement approaches (allows a broad and general categorization), 2) construct (a theoretical description of the content), 3) data type, 4) scoring recommendations, and 5) psychometric problems. Table 1 includes the previous taxonomies' original terminology and shows which of the aforementioned attributes are already represented in the taxonomy. As an example: The measurement types (Snyder, et al., 2019), task types (Benedek et al., 2019), measurement approaches (e.g., Batey, 2012), and measurement categories (e.g., Hocevar, 1981) all refer to the same attribute: the measurement approach (e.g., self-report). The attribute "construct" describes the underlying traits (e.g., imagination, Forgeard \& Kaufman, 2016; beliefs, Kaufman, 2019) or abilities measured (e.g., divergent thinking).

Based on these frameworks, we propose a taxonomy, including theoretically derived task attributes that combine, complement, and enrich previous categorization approaches (see Table 2). 


\section{Table 2}

A Taxonomy of Measuring Creativity, including Task Attributes.

\begin{tabular}{|c|c|c|c|c|c|c|}
\hline \multirow{2}{*}{$\begin{array}{l}\text { Task } \\
\text { Attributes }\end{array}$} & \multicolumn{2}{|c|}{ Self-report } & \multicolumn{2}{|c|}{ Other-report } & \multirow{2}{*}{\multicolumn{2}{|c|}{$\begin{array}{l}\text { Ability Tests } \\
\text { Performance }\end{array}$}} \\
\hline & Preferences & Accomplishments & Preferences & Accomplishments & & \\
\hline Construct & $\begin{array}{ll}\text { Creative } & \text { Creative } \\
\text { interests } & \text { Personality } \\
\text { and } & \text { (e.g., } \\
\text { attitudes } & \text { Ingenuity) }\end{array}$ & $\begin{array}{l}\text { Creative } \\
\text { achievements/activities } \\
\text { (e.g., on the job) }\end{array}$ & $\begin{array}{l}\text { Creative } \\
\text { attitudes \& } \\
\text { characteristics }\end{array}$ & $\begin{array}{ll}\text { Archival } & \text { Original } \\
\text { ratings } & \text { outcomes } \\
\text { (e.g., } & \text { (e.g., } \\
\text { eminent } & \text { patent } \\
\text { people) } & \text { indices) } \\
\end{array}$ & $\begin{array}{l}\text { Divergent } \\
\text { thinking } \\
\text { (fluency, } \\
\text { flexibility, } \\
\text { originality) }\end{array}$ & $\begin{array}{l}\text { Insight } \\
\text { problems }\end{array}$ \\
\hline Data type & $\begin{array}{l}\text { Questionnaire-data } \\
\text { (Cattell, 1958): } \\
\text { Subjective data }\end{array}$ & $\begin{array}{l}\text { Life-data (Cattell, 1958): } \\
\text { Biographical data }\end{array}$ & $\begin{array}{l}\text { Questionnaire-data } \\
\text { (Cattell, 1958): } \\
\text { Subjective data } \\
\end{array}$ & $\begin{array}{l}\text { Life-data (Cattell, } \\
\text { 1958): Objective data }\end{array}$ & $\begin{array}{l}\text { Test-data (C } \\
\text { Objective } \mathrm{d}\end{array}$ & $\begin{array}{l}\text { ttell, 1958): } \\
\text { a }\end{array}$ \\
\hline $\begin{array}{l}\text { Prototypical } \\
\text { Scoring }\end{array}$ & Average scale scores & $\begin{array}{l}\text { Sum of self-nominations } \\
\text { (rating-scale of } \\
\text { accomplishments) }\end{array}$ & $\begin{array}{l}\text { Averaging scale } \\
\text { scores/Agreement of } \\
\text { raters }\end{array}$ & $\begin{array}{l}\text { Agreement of } \\
\text { raters/experts: } \\
\text { Consensual } \\
\text { Assessment } \\
\text { Technique (CAT) }\end{array}$ & $\begin{array}{l}\text { Divergent } \\
\text { thinking: } \\
\text { Fluency, } \\
\text { flexibility, } \\
\text { originality } \\
\text { assessed by } \\
\text { agreement } \\
\text { of raters }\end{array}$ & $\begin{array}{l}\text { Insight: } \\
\text { proportion } \\
\text { attainment } \\
\text { of } \\
\text { objectively } \\
\text { correct } \\
\text { responses }\end{array}$ \\
\hline $\begin{array}{l}\text { Psychometric } \\
\text { Problems }\end{array}$ & $\begin{array}{l}\text { Introspection of the } \\
\text { individual; } \\
\text { Highly fakeable; } \\
\text { Shortcomings of self- } \\
\text { report; Evaluation of } \\
\text { originality, novelty, } \\
\text { and fluency; } \\
\text { Convergent Validity }\end{array}$ & $\begin{array}{l}\text { Introspection of the } \\
\text { individual; } \\
\text { Fakeable; } \\
\text { Shortcomings of self- } \\
\text { report; } \\
\text { Unusual data } \\
\text { distribution; } \\
\text { Convergent validity }\end{array}$ & $\begin{array}{l}\text { Convergent validity; } \\
\text { Inter-rater reliability: } \\
\text { familiarity with } \\
\text { creativity and } \\
\text { familiarity with the } \\
\text { target; } \\
\text { Artifact of the } \\
\text { assessment object }\end{array}$ & $\begin{array}{l}\text { Inter-rater reliability; } \\
\text { Bipartite definition of } \\
\text { creativity: usefulness } \\
\text { and novelty; } \\
\text { Domain-specific }\end{array}$ & $\begin{array}{l}\text { Divergent } \\
\text { Thinking: } \\
\text { Inter-rater } \\
\text { reliability; } \\
\text { intelligence } \\
\text { and speed } \\
\text { as sources } \\
\text { of variance }\end{array}$ & $\begin{array}{l}\text { Insight: } \\
\text { Assessmen } \\
\text { t of novelty } \\
\text { and } \\
\text { originality }\end{array}$ \\
\hline
\end{tabular}


It presents three major measurement approaches: self-report measures, other-report measures, and ability tests. These measurement approaches, at the apex of the hierarchy, offer a broad disjunct categorization. The measurement approaches are divided by preferences and accomplishments (self-, and other-reports) and performance. These subcategories are derived from different task requirements (preferences: report your/others typical behavior; accomplishments: frequency/rating of (previous) attainments; performance: produce creative ideas/solve a creative problem). Each of these measurement approaches require specification of further task attributes_constructs, data types, prototypical scoring, and specific psychometric problems - allowing a more precise categorization of a measure. Categorization of an assessment by measurement approach and construct allows an easy and straightforward categorization. The other task attributes offer a descriptive tool nested below the measurement approaches. The different data types usually come with a specific behavior of the participant and response style (Questionnaire data: Typical behavior reported on a Likert Scale; Lifedata: Maximal effort/skill-related typical behavior on a checklist; and Test-data: Maximal cognitive effort in open-ended answers). This leads to prototypical scoring recommendations (e.g., the consensual assessment technique; CAT, Amabile, 1982) and specific limitations.

\section{Creativity Measures Published Since the 1900s}

Previously published measures were identified based on a focused literature review, following a predefined protocol. We searched online using Google Scholar, Web of Science, Research Gate, PsycINFO, and in the Educational Testing Service (ETS) Test collection. We identified tests based on the following phrases, in different search engines: measures, assessment, questionnaire, test, creative, creativity, divergent thinking, flexibility, fluency, originality, ingenuity, gifted child, talent, eminent people, biographical, creative achievements, creative behavior, -interests, -attitudes, - styles, -personality. Additionally, we searched through previous reviews, special issues, and book chapters on creativity and its 
measurement, applying forward and backward search through the cited and citing literature. This for example included the APA's Division 10 database "Creativity and Arts Tasks and Scales: Free for Public Use" (https://osf.io/4s9p6/). This expands inclusion to measures not represented by the keywords. We included measures ranging from single-item to numerous items and scales. We excluded tests and articles that were limited in at least one of the following ways: (a) published only in languages other than English, (b) constructs only partially related to creativity—such as innovation (a key term that is primarily prevalent in business journals that describe practical realization of original ideas; Forgeard \& Kaufman, 2016) — or problem-solving; (c) were not published or at least applied in a (larger) empirical study that would allow an assessment of psychometric properties; and (d) did not provide item examples, which are obviously indispensable for further evaluation in this review. Indices that are applied to rate the creativity of a state or country (also including infrastructure or cultural environment) were also excluded (e.g., creative economy; Correia, 2014). We acknowledge that due to the exclusion criteria, tests that some researchers might regard as creativity tests are not included.

Figure 1 shows an overview of the $N=228$ measures identified in this review and their categorization by measurement approach and construct. Please note that a comprehensive list of all measures, including sample items and the original source of the measures, is available in the OSF (https://osf.io/e49n3/ ). Ability tests are most prominent in the literature $(n=132)$, followed by self-report measures $(n=59)$ and other report measures $(n=37)$. 


\section{Figure 1.}

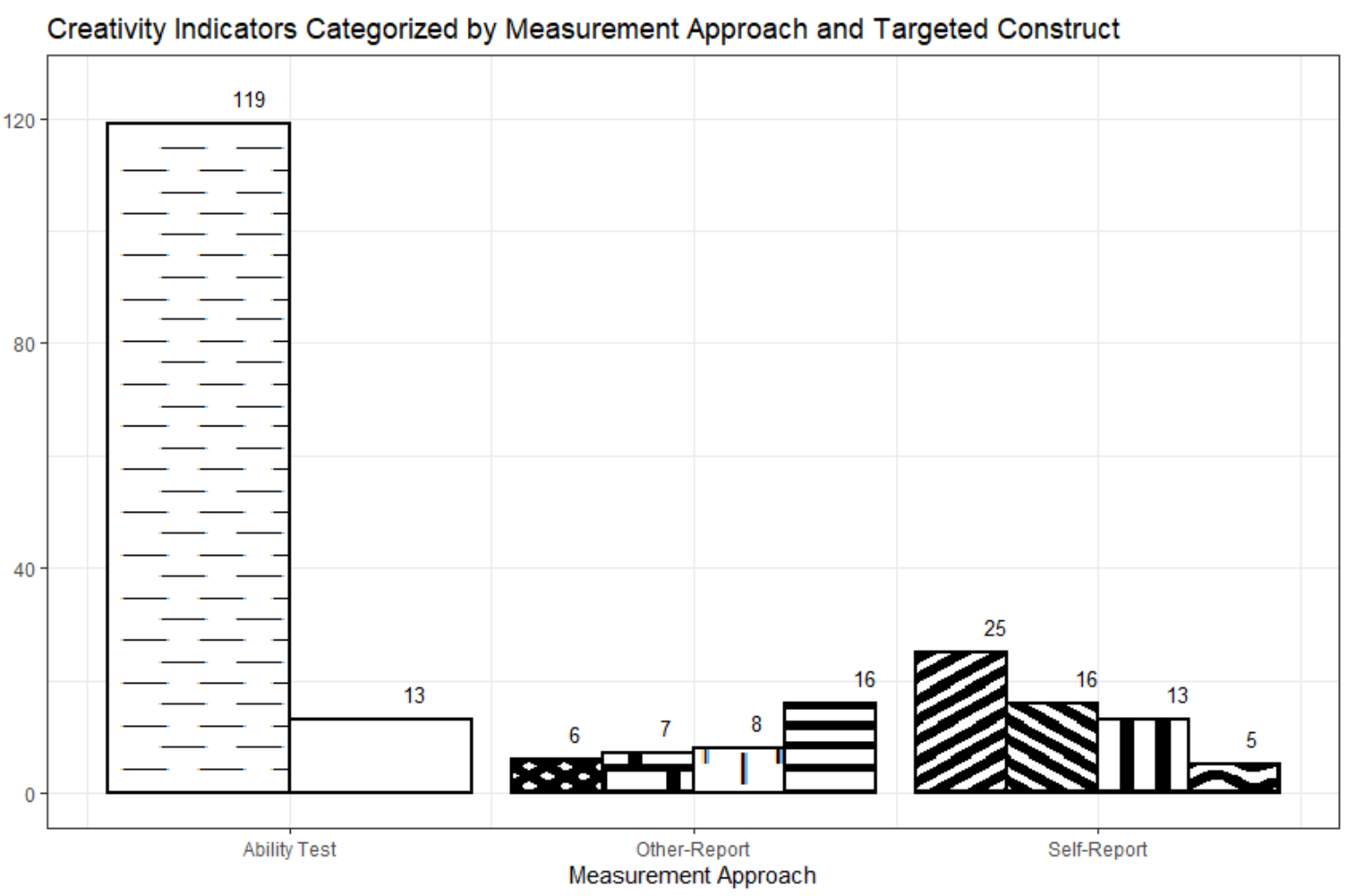

Note. Creativity indicators:

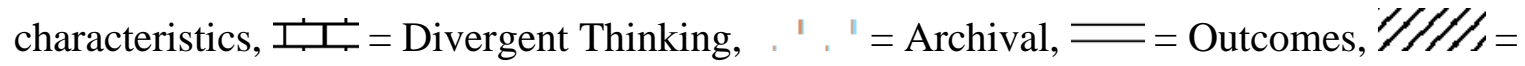

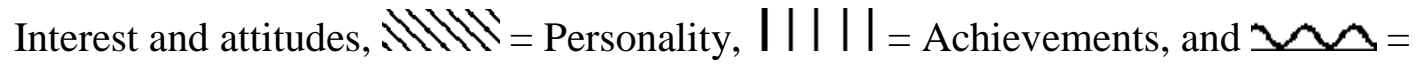
Activities.

\section{Applying the Proposed Taxonomy}

In the following paragraph, we first describe the results of two independent raters that categorized all tests presented in Figure 1 with respect to our proposed taxonomy. Next, we further apply the taxonomy, by providing a detailed description of all attributes and embed all the identified measures in the taxonomy.

The raters were provided with a general description of all constructs and a table including the test name, the author, and a minimum of one sample item (e.g., Write a paragraph about the theme "a tree"; Ekstrom, et al., 1976). Based on this table, the raters rated 
$(0=$ construct does not apply; $1=$ construct does apply $)$. These results are provided in the OSF (https://osf.io/e49n3/ ). After the rating, the agreement between the raters was analyzed based on Cohen's kappa (Cohen, 1960). Table 3 displays the kappa for categorizing the construct, along with the percentage of agreement. In a further meeting of raters' consensus for all categories was reached.

\section{Table 3}

Cohen's Kappa (k) and Percentage of Agreement for Two Independent Raters for the Measurement Construct and Construct.

\begin{tabular}{lcc}
\hline Construct & $\begin{array}{c}\text { Cohen's Kappa } \\
(\kappa)\end{array}$ & $\begin{array}{c}\text { Percentage of } \\
\text { Agreement }\end{array}$ \\
\hline Self-report (Construct: Interest \& Attitudes) & .84 & $97.4 \%$ \\
Self-report (Construct: Personality) & .83 & $97.4 \%$ \\
Self-report (Construct: Achievements) & .92 & $99.1 \%$ \\
Self-report (Construct: Activities) & .83 & $99.1 \%$ \\
Other-report (Construct: Divergent Thinking) & 1.00 & $100 \%$ \\
Other-report (Construct: Attitudes \& Interests) & 1.00 & $100 \%$ \\
Other-report (Construct: Archival) & 1.00 & $100 \%$ \\
Other-report (Construct: Outcome) & 1.00 & $100 \%$ \\
Ability Test (Construct: Divergent Thinking) & .99 & $99.6 \%$ \\
Ability Test (Construct: Insight) & 1.00 & $100 \%$ \\
\hline
\end{tabular}

\section{Self-Report}

In the following, we describe the measurement approach self-report, by defining its constructs, data-types, and scorings. Next, we present measures that have been identified as self-report measures of creativity.

Construct. First, measuring creative interests and attitudes consistently relies on selfreports as measurement approach (e.g., Hocevar, 1981). Creative attitudes can be defined as the degree of positive affect regarding creative dispositions, temperaments, and orientation, and predispose one to think creatively about a product (Davis, 1999). A person who shows creative interests enjoys being involved in creative activities (Slahova et al., 2007). These constructs are not further distinguished from one another as they lack clear segregation based on empirical data. Second, the study of personality investigates individual differences in 
behavior and thinking (Kazdin, 2000). Third, the construct of everyday creativity and creative achievement in self-reports describes minor, sometimes major, creative accomplishments in life and/or work (e.g., science) that enrich our everyday lives (Torrance, 1962; Lees-Haley, 1978; Bull \& Davis, 1980).

Data Type and Scoring. Self-reports are either based on the data type Q-data (Cattell, 1958) and hence on subjective data or L-data (Cattell, 1958), including biographical data. Qdata approaches are probably the most common form of assessment in psychology due to the ease of item development, scoring, and analysis of Likert-style items. L-data are gathered to describe previous creativity and creative behavior in various contexts based on the participants' introspection and self-evaluation. They can either include multiple-choice items, Likert-scale items (e.g., ranging from "never" to "more than ten times"; Diedrich et al., 2017) or open-ended answers (e.g., "Please name your overall five most creative achievements in your life so far.”, Diedrich et al., 2017). The participants are asked to report the frequency of previous creative actions and performances or provide information about the production of creative things. Q-data probe the participants' typical behavior, whereas L-data indicate skillrelated typical behavior or the report of maximal cognitive effort. Skill-related typical behavior includes behavior that requires a high degree of expertise (e.g., playing concert piano), but if this degree of expertise is reached, the behavior is more akin to typical behavior than maximal cognitive effort.

Measures. Table 4 presents all identified self-report questionnaires, including example items. Scales included in creative interests and attitudes are asking for the agreement with a provided behavior (e.g., "When I set goals for myself, I make sure they are openended.; Epstein Creativity Competencies Inventory for Individuals, Epstein et al., 2018). Creative Personality scales are mostly based on adjective checklists (e.g., "Divergent", Wechsler et al., 2012). In difference to creative interests and attitudes, the creative activities 
and achievements are based on biographical information (L-data), such as "how often have you carried out this activity over the past ten years: wrote a blog entry?" (Diedrich et al., 2017). This implies that creative activities and achievements are listed or the number of such events is indicated. Measures, not further listed in Table 4, because they have only been applied in very specific contexts are the Biographical Inventory for Students (Siegel, 1956) and specific workforce measures that have been mostly applied to identify creative personnel (research personnel, Buel, 1965; NASA scientists and engineers, Alpha Biographical Inventory, Institute for Behavioral Research in Creativity, 1968;e.g. Biographical Creativity Predictor for Scientific and Technical personnel, Erickson, Gantz, \& Stephenson, 1970; Biographical Inventory Creativity, Schaefer \& Anastasi, 1968). Additionally, the Achievement in Leadership questionnaire (e.g., Appointed to one or more offices; Holland \& Nichols, 1964) and the Life Experience Inventory (Michael \& Colson, 1979) include biographical data on creativity. 


\section{Table 4}

\section{Self-report Measures}

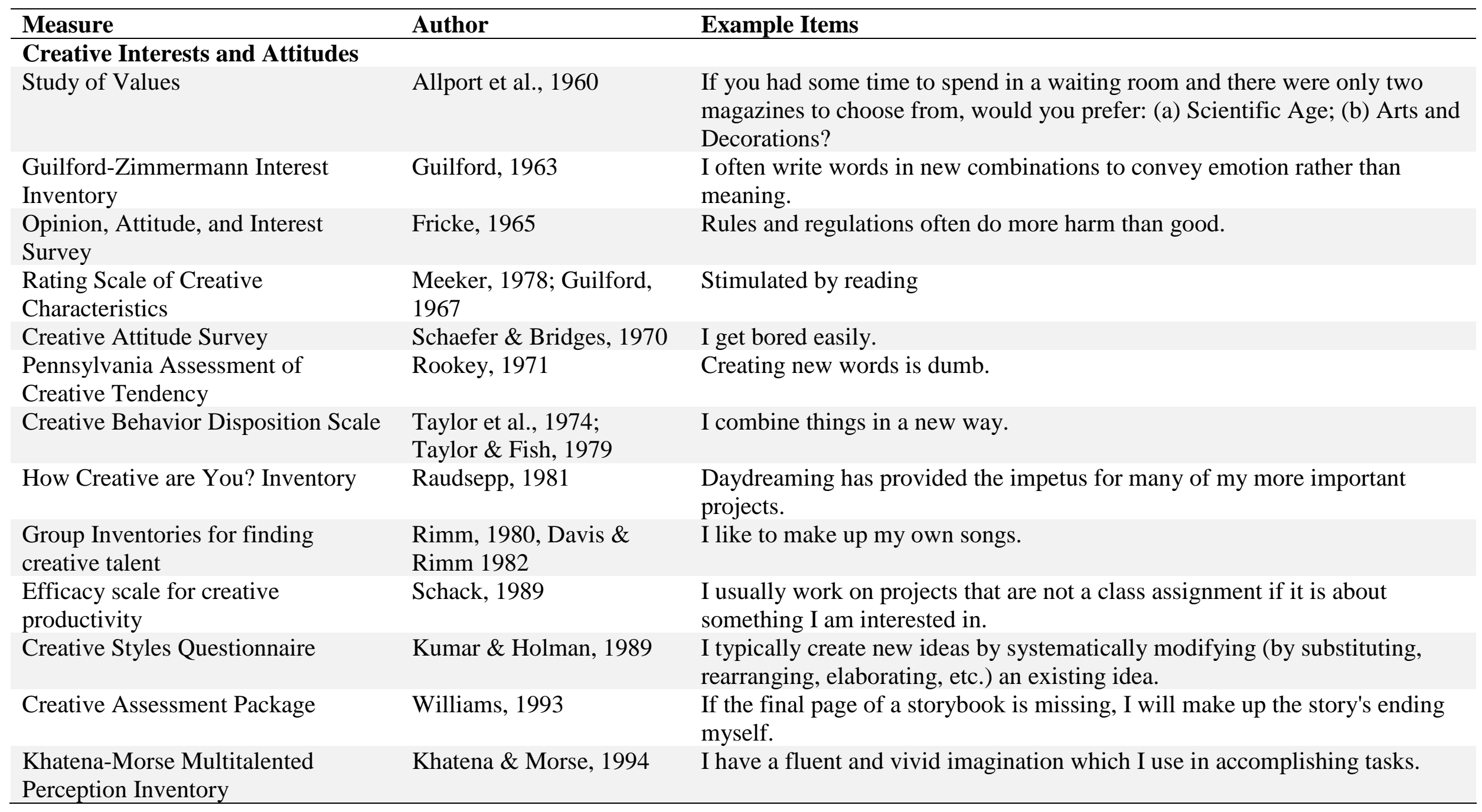




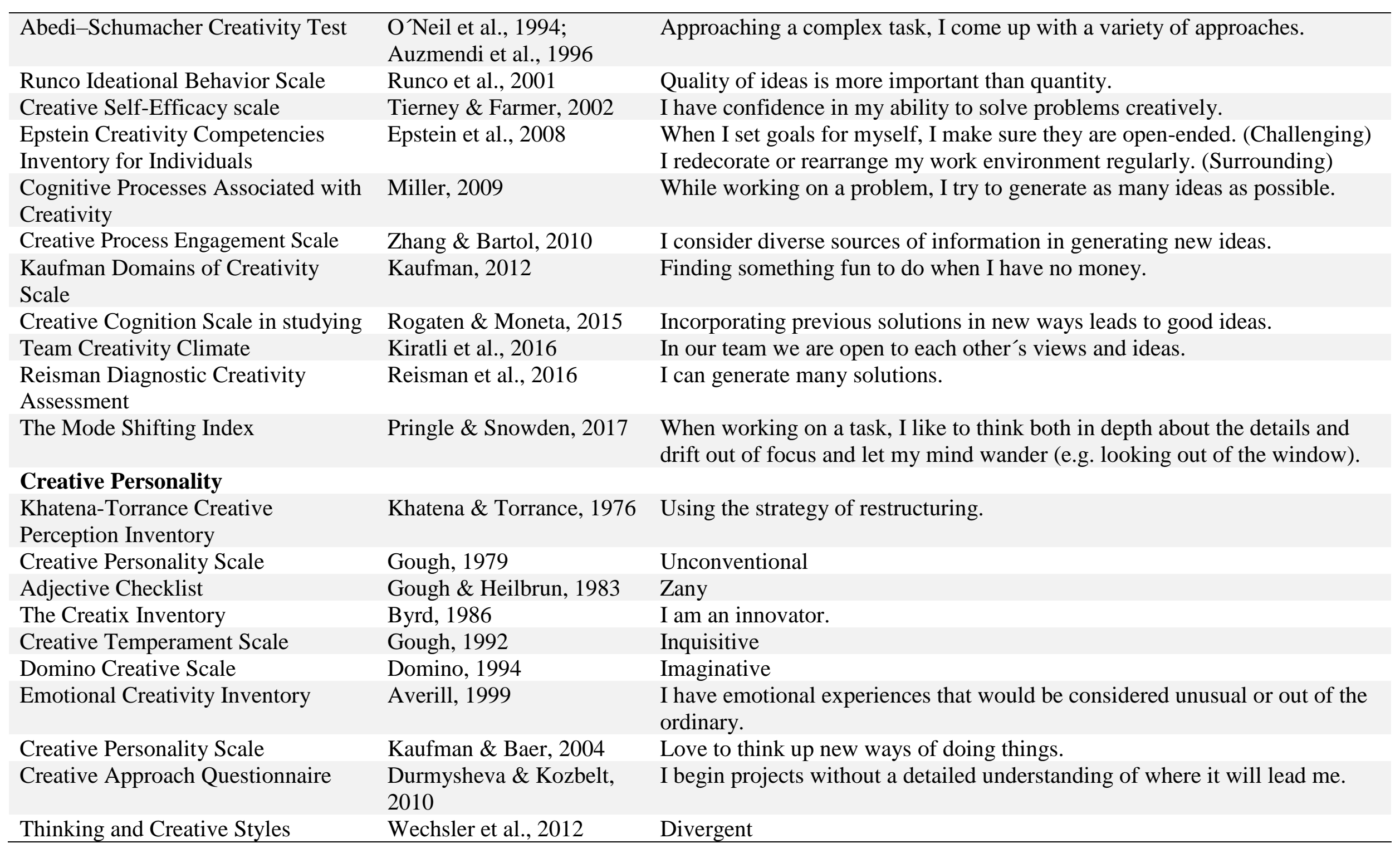




\section{Short Scale of Creative Self}

Karwowski et al., 2018

Creativity is an important part of myself.

\section{Creative Achievements/activities}

Independent Activities

Questionnaire

Achievement Checklist

Accomplishments Measures

Creativity Scale for different

Domains/ Creativity Domain

Questionnaire

Creative Behavior Inventory

Creative Achievement Questionnaire

Biographical Inventory of Creative

Behavior

Life-Space Questionnaire

Inventory of creative activities and

achievements

Schultz \& Skager, 1963;

Skager et al., 1965

Torrance, 1969b

Stricker et al., 2001

Kaufman \& Baer, 2004;

Kaufman et al., 2010

Dollinger, 2003

Carson et al., 2005

Batey \& Furnham, 2008

Ivcevic \& Mayer, 2009

Jauk et al., 2014; Diedrich et al., 2017, adapted after

Hocevar (1979)

Note. The participant should either rate their agreement on a Likert scale, agree or disagree or indicate how often they participated in the listed behavior. A few items were rephrased. Subscales from personality inventories are not further included for a reference see: International Personality Item Pool; Goldberg et al., 2006; Abridged Big 5 Circumplex (Hofstee et al., 1992; Johnson, 1994), Hogan Personality Inventory (Hogan \& Hogan, 1992), Jackson Personality Inventory-Revised (Jackson, 1994), Self-Directed Search questionnaire (Holland, Fritsche, \& Powell, 1997) 


\section{Other-Reports}

In the following, we describe the measurement approach other-reports, by defining its constructs, data-types, and scorings.

Construct. Creative attitudes, characteristics, and divergent thinking are constructs of other-reports (Table 2). Divergent thinking, or as Guilford (1950) labeled it, divergent production, is a cognitive process that produces original ideas in contrast to convergent thinking that results in a single correct answer. More details regarding divergent thinking are provided in the Constructs Section of Ability Tests. Creative attitudes and characteristics can be defined precisely as in self-report measures and are similar in what they measure, with the difference that they are based on significant others' ratings. Another construct assessed by experts (significant others') is ratings of archived products' originality and novelty from eminent persons. In this case, the measure is mostly based on products, actions, and past ideas.

Data Type and Scoring. Within the measurement approach of other-reports we summarize evaluations by peers, parent's reports, supervisor or teacher ratings, but also the ratings of experts that judge the creative amount of a product, performance, or action. The data type for the former includes questionnaire data (describing the typical behavior of a target often post-hoc), while the latter can be seen as L-data as it consists of the ratings of maximal effort of a person. Such expert-based assessments of performances have a long history and are often based on the prominently used CAT (Amabile, 1982). The CAT is based on the idea that the experts consent on the creativity of artwork, creative stories, or research proposals and that this consent is the best measure of creativity (Baer \& McKool, 2009). Typically, the participant is aware of the observation (e.g., the participant is applying for an award, attending a competition). 
Measures. The measures we have identified as other-report measures are presented in Table 5. Table 5 includes measures of creative attitudes and interests that are, similarly to measures of reported divergent production, mostly completed by parents and teachers. Other measures are focusing on the other-reported employee creativity (e.g., $\mathrm{Ng} \&$ Feldman, 2012). A meta-analysis identified 86 studies, of which $60 \%$ included some supervisory ratings of creativity and five percent peer ratings. Even though such ratings are applied and creativity is of high value for companies, explicitly published measures for this purpose are sparse (e.g., Baer \& Oldham, 2006; Madjar, Ortiz-Walters, 2008; Zhou \& George, 2001). The post-hoc evaluation and study of eminent people is one of the first attempts to measure and understand creativity and was applied before most other creativity measures. Analyzing archival data of eminent people provides insight into the creative process. Most eminent people have produced numerous ideas and outcomes, with only rare breakthroughs sometimes driven by luck and chance (e.g., Pasteur or Nobel; Cropley, 2006). Simonton referred to the analyses of historic individuals in his prominent historiometric approaches (Simonton, 1999). Historiomoteric approaches often include the quantity and the quality of creative productions. This has also led to several indices, such as the strict equal-odds, to study real creative outcome in terms of a linear function of quantity (e.g., Forthmann et al., 2021). Table 5 includes examples of ratings of archival data of eminent/historic people. For example, Cattell's (1903) study is based on rank-ordering the most eminent people based on the number of words written about the people in various biographical dictionaries. Based on this idea, the most creative architects, writers, biologists, and mathematicians were selected. 


\section{Table 5}

\section{Other-report Measures}

\begin{tabular}{|c|c|c|}
\hline Measure & Author & Example Item \\
\hline \multicolumn{3}{|c|}{ Creative Attitudes and Characteristics } \\
\hline $\begin{array}{l}\text { Parental Evaluation of } \\
\text { Childrens Creativity }\end{array}$ & Runco, 1989 & To what extent is this child imaginative? \\
\hline $\begin{array}{l}\text { Creative Assessment } \\
\text { Package }\end{array}$ & Williams, 1993 & My child has a vivid imagination. \\
\hline $\begin{array}{l}\text { Rating the Behavioral } \\
\text { Characteristics of } \\
\text { Superior Students }\end{array}$ & Renzulli et al., 2002 & $\begin{array}{l}\text { The student demonstrates creative thinking } \\
\text { about scientific topics }\end{array}$ \\
\hline $\begin{array}{l}\text { Gifted and Talented } \\
\text { Evaluation Scales }\end{array}$ & Gillian et al., 1996 & $\begin{array}{l}\text { The student demonstrates enthusiasm in } \\
\text { discussions of scientific topics }\end{array}$ \\
\hline Ideal Pupil Checklist & Torrance, 1975 & What kind of person is ... e.g., determined \\
\hline $\begin{array}{l}\text { Creative Behavior } \\
\text { Inventory } \\
\text { Divergent Thinking }\end{array}$ & Kirschenbaum, 1989 & This child notices and remembers details. \\
\hline $\begin{array}{l}\text { Characteristics of } \\
\text { Creative Children }\end{array}$ & Reid et al., 1959 & $\begin{array}{l}\text { My classmate has new ideas and new ways } \\
\text { of doing things. }\end{array}$ \\
\hline $\begin{array}{l}\text { Creative Dramatics } \\
\text { Test }\end{array}$ & Hensel, 1973 & The child has creative thinking abilities. \\
\hline $\begin{array}{l}\text { Gifted and Talented } \\
\text { Screening Form }\end{array}$ & Johnson, 1979 & The child is talented in creativity. \\
\hline Creativity checklist & Johnson, 1979 & The child has a preference for complexity. \\
\hline $\begin{array}{l}\text { Preschool and } \\
\text { Kindergarten Interests } \\
\text { Descriptors }\end{array}$ & Rimm, 1983 & My child tends to be very curious. \\
\hline $\begin{array}{l}\text { Leadership and } \\
\text { Employee Creativity }\end{array}$ & Tierney et al., 1999 & $\begin{array}{l}\text { The employee took risks in terms of } \\
\text { producing new ideas on the job. }\end{array}$ \\
\hline $\begin{array}{l}\text { Supervisor-ratings of } \\
\text { Creativity }\end{array}$ & $\begin{array}{l}\text { Zhou \& George, } \\
2001\end{array}$ & $\begin{array}{l}\text { Suggests many creative ideas that might } \\
\text { improve working conditions. }\end{array}$ \\
\hline \multicolumn{3}{|l|}{ Archival Data } \\
\hline Overall eminence & Cattell, 1903 & $\begin{array}{l}\text { Rank-ordering the } 1,000 \text { most eminent } \\
\text { people. }\end{array}$ \\
\hline Physical scientists & Roe, 1951 & $\begin{array}{l}\text { Rating the excellence of physical scientists } \\
\text { on a three-point scale. }\end{array}$ \\
\hline Leaders & Barron, 1969 & $\begin{array}{l}\text { Selecting and studying leaders in Irish } \\
\text { Economic life. }\end{array}$ \\
\hline Architects & $\begin{array}{l}\text { Hall \& MacKinnin, } \\
1969\end{array}$ & $\begin{array}{l}\text { Identifying and studying the } 40 \text { most } \\
\text { creative architects in the United States. }\end{array}$ \\
\hline Math & $\begin{array}{l}\text { Helson \& } \\
\text { Crutchfield, 1970; } \\
\text { Helson, 1971 }\end{array}$ & $\begin{array}{l}\text { Identifying the most creative researchers in } \\
\text { math and studying their achievements. }\end{array}$ \\
\hline Engineering & Chakrabarti, 2013 & $\begin{array}{l}\text { Studying the innovations of engineering } \\
\text { designers and innovators. }\end{array}$ \\
\hline Sports & Martin \& Cox, 2016 & Analyzing the moves of a basketball player. \\
\hline
\end{tabular}

Note. Ordered by publication year. A few items are reframed. For a more detailed overview of the study of eminent people until 1979, see Hovecar (1979) 
A further construct assesses the originality of outcomes (e.g., performances). Such measures are not further included in Table 5 but will be shortly summarized in the following. Typically, such expert ratings can involve indices of productivity (e.g., originality of ideas involving the US. Patent Index; Owens et al., 1957), that are used to assess employee creativity (Tierney et al., 1999). One scale explicitly designed for rating peak creativity in vocational but also avocational outcomes of others is the Lifetime Creativity Scale that provides several definitions in order to rate the levels of peak creativity (Richards et al., 1988). Besides, originality is often assessed in visual arts and poems (Cattell et al., 1918; Brittain \& Beittel, 1964; Csikszentmihalyi \& Getzels, 1970; Baer et al., 2004) or science (Harmon, 1963; Taylor et al., 1963). For example, competitions often include a judgment of originality and novelty (e.g., NYC radio contest: submit a humorous and original little green thing; Ward \& Cox, 1974). Judgments of product originality and novelty can also take place in school (e.g., mathematics and literature, Foster, 1971; creativity in writing, Wallen \& Stevenson, 1960). The abovedescribed evaluations such as stories, art, poetry, and aesthetic products (Amabile, 1982; Horn \& Salvendy, 2006; Cropley \& Kaufman, 2012; Jeffries, 2017) are rater-based assessments of creativity. The later examples, such as Baer and colleagues (2004) mostly apply the CAT technique (Amabile, 1982; Cseh et al., 2016) to assess product creativity in various domains (please note that an exhaustive list of CAT applications is beyond the scope of this article). Another scales for the judgment of work pieces is the Creative Solution Diagnosis Scale (Cropley \& Kaufman, 2012) that is applied for judging artworks, cartoons, t-shirts, novel chairs, and advertisements (Besemer \& O'Quin, 1986, 1987, 1999; White et al., 2002) and even mousetrap designs. Further scales are the Creativity Product Inventory (Taylor \& Sandler, 1972; Taylor, 1975), Creative Product Semantic Scale (O'Quin \& Besemer, 1989, e.g., a product is surprising and germinal), Student Product Assessment Form (Renzulli \& Reis, 1981), and the 
usability assessment in the area of technological and scientific products (Han et al., 2000; Cropley \& Kaufman, 2012).

\section{Ability Tests}

In the following, we describe the measurement approach ability tests, by defining its constructs, data-types, and scorings.

Construct. The application of ability tests in assessing creativity arguably began as part of the United States Army Air Force Aviation Psychology Program (Guilford, 1947). It continued in Guilford's Aptitudes Project carried out at the University of Southern California (Guilford et al., 1952). Guilford's 1950 Presidential Address to the American Psychological Association (Guilford, 1950) is often considered a turning point and strongly influenced the way creativity was perceived. Wilson and colleagues (1954) administered 53 tests and ran a factor analytic study of primary abilities, such as the constructs of fluency, flexibility, and the production of novel ideas, a few years later. This resulted in 46 different divergent thinking tests categorized by 14 constructs of creative thinking ability that are not further referred to in this review (a complete list of these measures is provided in the Ability Tests Measure section). Please note, as pointed out by an anonymous reviewer, earlier work on the measurement of originality went unrecognized by Wilson and colleagues but that earlier work had suggested similar measurement approaches (see Chassell, 1916). Later, Guilford (1956, 1986) claimed that divergent thinking is comprised of fluency (quantity of adequate responses), flexibility (number of category switches between responses within a task), originality (classifying the rarity, cleverness, and originality of a response within a sample), and elaboration (amount of details given in an answer). Nevertheless, divergent thinking tests cannot be easily subdivided by fluency, flexibility, and originality. These aspects represent scoring methods, and many tests are scored on more than one dimension (e.g., originality and quantity of named things; Carroll, 1993). 
Besides divergent thinking, the other creativity construct in ability measures includes insight performance in creative problems (Polya, 1945). Insight describes the process of solving a problem (Mayer, 1995) and has often been related to major scientific discoveries and creativity (Cropley, 2006; Finke, 1995). Many insight problems (i.e. Duncker's candle problem) have their origin in earlier gestalt-psychology. Insight is only involved when solving novel and non-routine problems and includes a shift of perspective (Dow \& Mayer, 2004). This shift of perspective and discovering new ideas are also referred to as the Eureka moment (Vallée-Tourangeau, 2018; Sprugnoli et al., 2017). Insight tasks are often employed as creativity tasks (e.g., Gibson et al., 2009; Martindale et al., 1984). They are meant to facilitate creative solutions because of their nature of linking remote ideas or words (Mednick \& Mednick, 1967).

Data Type and Scoring. In most divergent thinking tasks, participants are asked to generate ideas or react to a spatial or verbal prompt (Kim, 2006). The tasks are used to gather objective test-data by subjects providing open-ended responses. The behavior measured here is maximal cognitive effort. Performance on insight tasks is usually expressed as the proximity to a pre-defined solution. Insight tasks can be verbal, mathematical, or spatial problems that are all featured by one correct answer. Hence, they are often scored as the participants` proportional attainment of an objective response standard.

Measures. Many divergent thinking tests go back to the tests Wilson and colleagues have proposed (1954). Unfortunately, earlier tests as proposed by Chassell (1916) are buried in oblivion. Chassell (1916) proposed twelve originality tests that also show similarities to later developed tests (e.g., such as coming up with economic prophecies or novel situations). The tests presented by Chassell show some similarities with later proposed insight tests. However, these tests have open response format and provide credit to more than one solution. Therefore, we classify them as divergent thinking tests. The tests presented later on by Wilson 
included, for example, Brick Uses/Unusual Uses ("List different uses for a brick."),

Consequences Test ("List consequences of certain changes."), and Plot Titles ("Write titles for story plots: fluency score/originality score."). The tests include verbal, numerical, or spatial content. For an exhaustive list of measures (including earlier measures of Chassell, 1916), please see the list provided in the OSF. In Table 6 we present a variety of general divergent thinking tests developed after Wilson et al. (1954), mostly applied for adults (please note divergent thinking tests for specific contexts (e.g., music) or groups (e.g., children) are described in the later text sections).

\section{Table 6}

Ability Tests: Divergent Thinking Spatial and Verbal for Adults (after Wilson et al., 1954)

\begin{tabular}{|c|c|c|}
\hline Measure & Author & Example Items \\
\hline $\begin{array}{l}\text { Consequences } \\
\text { Task }\end{array}$ & $\begin{array}{l}\text { Christensen et al., } \\
1958\end{array}$ & $\begin{array}{l}\text { Imagine that people no longer needed to sleep. } \\
\text { What would happen as a consequence? }\end{array}$ \\
\hline $\begin{array}{l}\text { Test of Creative } \\
\text { Ability }\end{array}$ & $\begin{array}{l}\text { Industrial Relations } \\
\text { Center, 1959; Harris } \\
\text { \& Simberg, } 1959\end{array}$ & $\begin{array}{l}\text { List all possible uses for an ordinary wire coat } \\
\text { hanger. }\end{array}$ \\
\hline $\begin{array}{l}\text { Alternate Uses } \\
\text { Task }\end{array}$ & $\begin{array}{l}\text { Christensen et al., } \\
1960\end{array}$ & List all the different ways you could use a chair. \\
\hline Line Meanings & Tagiuri, 1960 & What does this line make you think of? \\
\hline $\begin{array}{l}\text { Minnesota Tests } \\
\text { of Creative } \\
\text { Thinking and } \\
\text { Writing }\end{array}$ & Yamamoto, 1964 & $\begin{array}{l}\text { What questions can you think about the things } \\
\text { you see in the picture? }\end{array}$ \\
\hline Instances Task & $\begin{array}{l}\text { Wallach \& Kogan, } \\
1965\end{array}$ & $\begin{array}{l}\text { Write down all of the unusual, creative, and } \\
\text { uncommon instances of things that are round. }\end{array}$ \\
\hline $\begin{array}{l}\text { Wallach-Kogan } \\
\text { Test }\end{array}$ & $\begin{array}{l}\text { Wallach \& Kogan, } \\
1965\end{array}$ & $\begin{array}{l}\text { Tell me all the ways in which an apple and } \\
\text { orange are alike. (Similarities) }\end{array}$ \\
\hline $\begin{array}{l}\text { Torrance Test of } \\
\text { Creative Thinking }\end{array}$ & Torrance, 1966 & What might this picture show? \\
\hline Plot Titles & $\begin{array}{l}\text { Berger \& Guilford, } \\
1969\end{array}$ & Provide appropriate titles for a story. \\
\hline $\begin{array}{l}\text { Incomplete } \\
\text { Figures }\end{array}$ & Torrance, $1969 \mathrm{a}$ & Complete a given figure. \\
\hline $\begin{array}{l}\text { Picture } \\
\text { construction from } \\
\text { dots }\end{array}$ & Torrance, $1969 \mathrm{a}$ & Construct a picture out of dots. \\
\hline $\begin{array}{l}\text { Comprehensive } \\
\text { Ability Battery }\end{array}$ & $\begin{array}{l}\text { Hakstian \& Cattell, } \\
1975\end{array}$ & $\begin{array}{l}\text { Generate ideas and alternative uses in applied } \\
\text { arts, sales, marketing, consulting, and teaching. }\end{array}$ \\
\hline
\end{tabular}




\begin{tabular}{|c|c|c|}
\hline $\begin{array}{l}\text { Combining } \\
\text { Objects }\end{array}$ & $\begin{array}{l}\text { Ekstrom et al., } \\
1976 \text {; French et al., } \\
1963\end{array}$ & $\begin{array}{l}\text { Name two objects, when used together, fulfill a } \\
\text { particular request. }\end{array}$ \\
\hline Substitute Uses & $\begin{array}{l}\text { Ekstrom et al., } \\
\text { 1976; French et al., } \\
1963\end{array}$ & $\begin{array}{l}\text { Think of a common object that could serve as a } \\
\text { substitute for a given purpose. }\end{array}$ \\
\hline Making Groups & $\begin{array}{l}\text { Ekstrom et al., } \\
\text { 1976; French et al., } \\
1963\end{array}$ & $\begin{array}{l}\text { Combine given items in a group and provide a } \\
\text { reason for grouping them. }\end{array}$ \\
\hline Different Uses & $\begin{array}{l}\text { Ekstrom et al., } \\
\text { 1976; French et al., } \\
1963\end{array}$ & Provide other uses for a magazine. \\
\hline Toothpicks Test & $\begin{array}{l}\text { Ekstrom et al., } \\
\text { 1976; French et al., } \\
1963\end{array}$ & $\begin{array}{l}\text { Make different patterns of squares outlined by } \\
\text { toothpicks. }\end{array}$ \\
\hline Planning Patterns & $\begin{array}{l}\text { Ekstrom et al., } \\
\text { 1976; French et al., } \\
1963\end{array}$ & Fit figures onto a group of dots. \\
\hline Storage Test & $\begin{array}{l}\text { Ekstrom et al., } \\
1976 \text {; French et al., } \\
1963\end{array}$ & Store objects in a given space. \\
\hline $\begin{array}{l}\text { Word Endings } \\
\text { Test }\end{array}$ & $\begin{array}{l}\text { Ekstrom et al., } \\
\text { 1976; French et al., } \\
1963\end{array}$ & Write words that are ending in ATE. \\
\hline $\begin{array}{l}\text { Word Beginnings } \\
\text { Test }\end{array}$ & $\begin{array}{l}\text { Ekstrom et al., } \\
1976 \text {; French et al., } \\
1963\end{array}$ & Think of words that are beginning with RE. \\
\hline $\begin{array}{l}\text { Word Beginning } \\
\text { and Ending Tests }\end{array}$ & $\begin{array}{l}\text { Ekstrom et al., } \\
\text { 1976; French et al., } \\
1963\end{array}$ & $\begin{array}{l}\text { Think of words beginning with } \mathrm{S} \text { and ending } \\
\text { with } \mathrm{N} \text {. }\end{array}$ \\
\hline Opposites Test & $\begin{array}{l}\text { Ekstrom et al., } \\
\text { 1976; French et al., } \\
1963\end{array}$ & $\begin{array}{l}\text { Try to think about some words which mean the } \\
\text { opposite of the word easy. }\end{array}$ \\
\hline $\begin{array}{l}\text { Controlled } \\
\text { Associations Test }\end{array}$ & $\begin{array}{l}\text { Ekstrom et al., } \\
1976 \text {; French et al., } \\
1963\end{array}$ & Write as many synonyms for the word short. \\
\hline $\begin{array}{l}\text { Figure of Speech } \\
\text { Test }\end{array}$ & $\begin{array}{l}\text { Ekstrom et al., } \\
\text { 1976; French et al., } \\
1963\end{array}$ & $\begin{array}{l}\text { Try to think about words and phrases that } \\
\text { complete the figure of speech: the jewels } \\
\text { sparkled like... }\end{array}$ \\
\hline Making Sentences & $\begin{array}{l}\text { Ekstrom et al., } \\
\text { 1976; French et al., } \\
1963\end{array}$ & $\begin{array}{l}\text { Write a sentence contain words that begin with } \\
\text { the letters } E-R-T\end{array}$ \\
\hline Arranging Words & $\begin{array}{l}\text { Ekstrom et al., } \\
\text { 1976; French et al., } \\
1963\end{array}$ & $\begin{array}{l}\text { Write sentences containing the words TAKE - } \\
\text { FEW - LAND - LITTLE }\end{array}$ \\
\hline Rewriting & $\begin{array}{l}\text { Ekstrom et al., } \\
\text { 1976; French et al., } \\
1963\end{array}$ & $\begin{array}{l}\text { Rephrase the sentence "In response to the } \\
\text { teacher's question, a forest of hands shot up." }\end{array}$ \\
\hline
\end{tabular}




\begin{tabular}{|c|c|c|}
\hline Ornament Test & $\begin{array}{l}\text { Ekstrom et al., } \\
\text { 1976; French et al., } \\
1963\end{array}$ & Decorate a plain lampshade in different ways. \\
\hline Elaboration Test & $\begin{array}{l}\text { Ekstrom et al., } \\
\text { 1976; French et al., } \\
1963\end{array}$ & Add details on a playing card. \\
\hline Symbols Test & $\begin{array}{l}\text { Ekstrom et al., } \\
\text { 1976; French et al., } \\
1963\end{array}$ & Draw symbols that represent the word food. \\
\hline Topics Test & $\begin{array}{l}\text { Ekstrom et al., } \\
\text { 1976; French et al., } \\
1963\end{array}$ & $\begin{array}{l}\text { Write as many ideas you can think of about "A } \\
\text { train Journey". }\end{array}$ \\
\hline Theme Test & $\begin{array}{l}\text { Ekstrom et al., } \\
\text { 1976; French et al., } \\
1963\end{array}$ & Write a paragraph about the theme "a tree". \\
\hline $\begin{array}{l}\text { Thing Categories } \\
\text { Test }\end{array}$ & $\begin{array}{l}\text { Ekstrom et al., } \\
\text { 1976; French et al., } \\
1963\end{array}$ & $\begin{array}{l}\text { List things that are always red or that are red } \\
\text { more often than any other color. }\end{array}$ \\
\hline American Haiku & Amabile, 1985 & $\begin{array}{l}\text { Write a five-line, unrhymed poem, following a } \\
\text { series of steps. }\end{array}$ \\
\hline $\begin{array}{l}\text { Emotional } \\
\text { Consequences }\end{array}$ & $\begin{array}{l}\text { Averill \& Thomas- } \\
\text { Knowles, } 1991\end{array}$ & $\begin{array}{l}\text { What would happen if people would fall in love } \\
\text { with a different person every day? }\end{array}$ \\
\hline $\begin{array}{l}\text { Creative } \\
\text { Assessment } \\
\text { Package }\end{array}$ & Williams, 1993 & $\begin{array}{l}\text { Incomplete Figures that must be complited by } \\
\text { drawing. Come up with a title for each drawn } \\
\text { figure. }\end{array}$ \\
\hline $\begin{array}{l}\text { Word } \\
\text { rearrangement } \\
\text { test }\end{array}$ & $\begin{array}{l}\text { Fillis \& McAuley, } \\
2000\end{array}$ & $\begin{array}{l}\text { Construct a story that contains as many of the } \\
\text { presented words as possible. }\end{array}$ \\
\hline Aurora Project & Chart et al., 2008 & $\begin{array}{l}\text { Imagine that the world changed so that almost } \\
\text { everything can speak. Write a little conversation } \\
\text { describing what the two things listed might say } \\
\text { to each other if they could talk. Each thing must } \\
\text { say at least one thing. Before you write what } \\
\text { they will say, circle who is speaking. }\end{array}$ \\
\hline $\begin{array}{l}\text { Situational } \\
\text { Originality }\end{array}$ & $\begin{array}{l}\text { Antonietti et al., } \\
2011\end{array}$ & $\begin{array}{l}\text { Choose three things, between the listed words to } \\
\text { describe a tennis game. }\end{array}$ \\
\hline $\begin{array}{l}\text { Kaleidoscope } \\
\text { Project }\end{array}$ & Sternberg, 2012 & $\begin{array}{l}\text { Share a one-minute video that says something } \\
\text { about oneself. }\end{array}$ \\
\hline $\begin{array}{l}\text { Cued Creativity } \\
\text { Verb Generation } \\
\text { Task }\end{array}$ & $\begin{array}{l}\text { Prabhakaran et al., } \\
2014\end{array}$ & $\begin{array}{l}\text { Say a creative verb that is related to the noun } \\
\text { scissors. }\end{array}$ \\
\hline
\end{tabular}

Note. Tests are ordered by publication year. A few items are rephrased.

One very prominent divergent thinking test, included in Table 6, is the Torrance Test of Creative Thinking (Torrance, 1966). The test includes verbal (e.g., "Improve products") and spatial subtests (e.g., "What might this picture show?"), that are combined in one sum score. The test is based on fluency, flexibility, and originality aspects of creativity. It includes 
verbal subtests such as asking, guessing causes, guessing consequences, product improvement, unusual uses, unusual questions, and spatial subtests such as picture construction, picture completion, and lines and circles. The spatial test is assumed to be a culture-fair instrument as it is only based on minimal language. In a 50-year follow-up longitudinal study, the scores obtained in late 1950 were correlated to current personal and public achievement. It was found that these scores were moderately correlated with personal achievement, but not with public achievement (Runco et al., 2010).

There are a number of tests that are not included in Table 6, as they are rather specific. This includes measures that assess creativity in art and music: The Denny-Ives Creativity Test (e.g., redefinition in dramatic art; Rusch et al., 1964); Hall Mosaic Construction Test (Hall, 1972), spatial creativity and alien drawing (Niu \& Sternberg, 2001), Measure of Creativity in Music and Sounds (Baltzer, 1988), Measures of Musical Divergent Production (Gorder, 1980; Richardson \& Saffle, 1983), Onomatopoeia and Images (Torrance et al., 1973), Thinking Creatively with Sounds and Words (Torrance et al., 1973, Houtz, 1985), Musical Expression Test (Barbot \& Lubart, 2012), Creative Thinking in Music (Webster, 1994), and Musical Originality (Coffman, 1992). Test not included in Table 6, as they are specifically for the occupational context are: Owens' Creativity Task for Machine Design (Owens, 1960), Purdue Creativity Test (e.g., generate flexible ideas to solve job-related problems, Lawshe \& Harris, 1960), Creative Engineering Design Assessment (Charyton \& Merrill, 2009), Formulating Hypotheses Test (Frederiksen et al., 1975), and The Scientific Word Association Test (Gough, 1975; Gough 1976). Lastly, we describe we summarize specific divergent thinking tests for children, that were also excluded from Table 6: Divergent Movement Ability Test (Cleland, 1994), Thinking Creativity in Action and Movement (Torrance \& Gibbs, 1977), Starkweather Creativity Tests available for pre-school children (Starkweather, 1971), the Purdue Elementary Problem Solving Inventory (Feldhusen et al., 1972), the Gross Geometric 
Forms Test (Gross \& Marsh, 1970), and the originality of forms test that consists of threedimensional abstract forms (Starkweather, 1974). The Barron-Welsh Art Scale is a Freudianbased assessment in which the participant is asked to draw a picture. The pictures are scored on various scales, including personal styles and social attitudes (Welsh \& Barron, 1959). The Test for Creative Thinking-Drawing Production (Jellen \& Urban, 1989) uses a set of eleven criteria to assess the creativity of a drawing produced by elementary school children. Other tests that have been applied in the school context are the Creative Reasoning Test (Doolittle, 1989) and the Evaluation of Potential Creativity (Lubart et al., 2011). A more recent approach for measuring scientific creativity in children is the Creative Scientific Ability Test (Ayas \& Sak, 2014). The test measures fluency, flexibility, hypothesis testing, generation, and evidence evaluation in five subtests that are allocated to the fields of Biology, Interdisciplinary Science, Chemistry, Physics, and Ecology.

The second construct in ability tests includes creative insight problems. In classic insight problems, the participant is asked to provide one correct solution. Historically, Gestaltpsychological problems were used to study insight performance (e.g., Köhler, 1967). Insight has been traditionally studied with problems such as the Nine-dot Problem, the Dunker Candle Task, and the The Triangle of Coins (for an overview, see Chu \& MacGregor, 2011). Besides these classic insight tasks, Chu and MacGregor (2011) also reviewed newer insight problems, such as Matchstick Arithmetic (Knoblich et al., 1999), Compound Remote Associates (Bowden \& Jung-Beeman, 2003), or Remote Associate Tasks (Mednick \& Mednick, 1967) or Rebus Puzzles (MacGregor \& Cunningham, 2008). In the Remote Associate Task, the participants are asked to produce a remote associate to a given word. Other typical insight problem tasks are anagrams (Novick \& Sherman, 2003) and riddles (Luo \& Niki, 2003) as a measure of word imagery representing verbal problems (Dewing \& Hetherington, 1974). Word analogies have also been assessed together with different 
instructions (such as "Think more creatively about whether the four-word set constitutes a valid analogy.”, Green et al., 2012). Another verbal task is the brainteaser (Sheth et al., 2009), while the binarized images (Giovannelli et al., 2010) are task-based on pictorial stimuli. All these tasks are also described in Sprugnoli and colleagues' (2017) and Chus and MacGregors' (2011) review of human performance on insight tasks. A further, more recent test is the Design Thinking Creativity Test (Hawthorne et al., 2016) that presents problem-solving skills within the twenty-first century and is based on design thinking principles. Here the individuals must develop a "useful and meaningful” design solution (Plattner et al., 2015).

\section{Psychometric Problems of the Measurement Approaches}

In the next sections, we complete the application of our taxonomy by presenting psychometric shortcomings of each measurement approach.

\section{Self-Reports}

Self-report measures are susceptible to several sources of bias-social desirability, reference and response style biases. In the assessment of creativity, individuals' introspection might be problematic (e.g., Baas et al., 2015). There has been much effort in the development of creativity self-report measures within the last few years (e.g., Forgeard \& Kaufman, 2015; Kaufman, 2019; Silvia et al., 2012), and recent measures often show acceptable to good reliability (e.g., Revised Creative Domain Questionnaire: $\alpha=.82$; the Biographical Inventory of Creative Behaviors $\alpha=.74$; Silvia et al., 2012). However, reliability as estimated by Alpha reflects consistency in responding, and that consistency can be inflated by the consistency of biases. A way to get around this is by considering correlations with non-self-report measures of creativity. However, there seems to be a general problem of convergent validity given the low correlations often found between tests of divergent thinking and self-report measures (e.g., $r=.16$; Kandler et al., 2016). Such low correlations suggest that different constructs are 
measured or severe reliability problems are an issue with at least one of the two constructs. Besides, self-reports are prone to various self-report biases (e.g., social desirability, acquiescence, malingering, etc.). As mentioned above, the self-report measures (Q-data and L-data) reported in our review require some amount of introspection of the individual. This can be problematic as individuals may understand the question, item, or response options differently (Weiss \& Roberts, 2018) or show an incongruence between their beliefs regarding creativity and the actual scientific evidence (Baas et al., 2015). This can lead to low reliability of a self-report scale and low convergent validity with ability measures. This leads to the question of how well an individual (or others') can rate themselves (or others') on a selfreport if researchers are still struggling to define and understand creativity. Another vital issue displayed in self-reports (especially the Q-data) is that the fixed choice questions lack flexibility and force people to respond. Many Q-data items are not in line with the bipartite nature of the definition of creativity, as they are very specific and often do not meet the definition.

Furthermore, these items lack a real test of the people's ability to be original and fluently produce novel ideas. The measures that are identified as Q-data are also not easy to distinguish from other close constructs. For example, there might be a substantial overlap between personality self-report and creativity self-report items. This overlap is further described in the discussion. Hence, practitioners must use these items carefully to avoid jingle-jangle fallacies. The measures, including L-data, also require introspection regarding an extended period, and some participants might not be able to report any creative achievements.

\section{Other-Reports}

Other-reports are common across student and class evaluation by teachers, peers or parents, and the workplace (e.g., supervisor-ratings). Ratings can be based on various events and situations, and the raters can have different expertise and biases. Drevdahl (1956) showed 
that teachers' nominations were not significantly different when the teachers were given a clearly defined concept of creativity and were clearly instructed. However, parents' ratings are often only weakly related to teachers' ratings of the students' creativity (Runco, 1989). Meta-analytic studies provide evidence that the frequency of interaction with the target and especially interpersonal intimacy is necessary to substantially increase the accuracy of otherrating on personality (Connelly \& Ones, 2010). Besides, the data of human raters are intrinsically nested. Such nestedness and the effects of the human coding should preferably be part of the statistical modeling, as, applied in specific item response theory models, that account for item and rater-characteristics (e.g., Robitzsch \& Steinfeld, 2018).

Other-reports are often highly domain-specific and there are several reasons why ratings of others can diverge. As such discrepancy between any kind of raters can be due to differences in the construct understanding or even domain expertise (e.g., Amabile, 1996), it is important that standardized instructions for raters are applied as well as standardized test material (e.g., the granularity of the Likert-scale; Cseh \& Jeffries, 2019). In conclusion, all other-ratings can be psychometrically problematic if the rater is not familiar with the target (e.g., the person or the rated creative outcome) or the rated construct. However, assessing eminent people by the fluency or the originality and novelty of products is a promising approach.

\section{Ability Tests}

Divergent thinking tasks are the most prominent tasks in measuring creativity and the tasks that have arguably better validity, reliability, and predictive power for relevant outcomes. One of the major challenges comes with scoring of divergent thinking tasks(e.g., Cseh \& Jeffries, 2019). First, the scoring should be in line with the instruction. This implies that the participants should be only scored on the dimension that was instructed and measured (e.g., a task in which participants were instructed to be fluent, their fluency and nothing else 
should be the target of the performance appraisal, while tasks that ask for an original answer should evaluate performance according to originality standards). Second, free-response formats requires some human judgments. The relevance of these judgments can be part of the response modeling (e.g., see Robitzsch \& Steinfeld, 2018 for models that account for different rater characteristics). The next challenges arise when it comes to the dimension (e.g., originality) of the score that is derived from the data (for an overview see Reiter-Palmon et al., 2019). Fluency scores that are easy to derive can be criticized concerning their dependability on the ability to retrieve information (e.g., broad retrieval ability highly predicts creative fluency, Silvia et al., 2013). Flexibility scores are often based on arbitrary classification systems that have varying granularity of categories. Originality scores can be problematized with regard to the lack of generally recognized standards and protocols, and more often than not for the low agreement between raters. Another general shortcoming that is not further related to the scoring issues described above is that most divergent thinking tasks are time-constrained and based on verbal or spatial expressions. This indicates that general intelligence and cognitive speed are relevant sources of variance although that may not be intended. In order to overcome some of these issues, Forthmann and colleagues (2017) described modern approaches for scoring divergent thinking tasks, including computerized frequency scorings, associational remoteness based on latent semantic analysis, and a snapshot scoring for cleverness based on three human raters (e.g., Silvia et al., 2009).

Insight tasks are easy to score, but there is a question about their relation to creativity. Insight tasks require a correct response, but there is no possibility of assessing a person's novelty or originality. It may be challenging to evaluate details of response processes a person was applying to solve the problem. The convergent nature of insight tasks—one veridical answer - questions their applicability of creativity tasks and their detachability of typical convergent thinking (aka intelligence) tests. In fact, famous insight tasks, such as the Remote 
Associate Task (Mednick \& Mednick, 1967), are used to assess both convergent thinking and divergent thinking. Therefore, some researchers argue insight is an important part of creativity (e.g., Weiss et al., 2020), while others describe no correlations with creativity but rather with intelligence and motivation (e.g., Shaw \& Conway, 1990).

\section{Creativity Measures: Construct Validity}

Based on the vast range of measures embedded in our taxonomy, we must ask whether all these measures really assess a coherent dispositional trait best labeled as creativity.

Similarly, it has to be asked if there is at least some coherence regarding the dispositional trait within the constructs. Situations in which different phenomena are subsumed below the same label are referred to as jingle fallacies (Thorndike, 1904). For example, self-reported creative activities and achievements are highly correlated with other creative achievement self-reports ( $r=.68$; Jauk et al., 2014), which can be taken as proof of convergent validity. On the other hand, creative activities are only weakly predicted by fluency $(\beta=.22)$ and originality $(\beta$ $=.25$ ), and the relation between creative achievements and fluency/originality was mediated by creative activities (Jauk, et al., 2014). This study therefore consequently distinguishes between divergent thinking measures, creative activities, and creative achievements as they do not measure the same underlying construct. Nevertheless, the literature often presents results regarding creativity that do not distinguish between the substantial differences associated with the measurement approaches and constructs.

Assigned to our taxonomy, this situation would indicate that all measures proposed as creativity measures should be related to one another - i.e., they should demonstrate a positive manifold. If this positive manifold is not confirmed, we would, at the very least, recommend relabeling variables of interest to indicate that they do not measure the same underlying construct. Additionally, other things being equal, any two creativity measures should be correlated more highly with each other than with non-creativity indicators. For example, the 
correlation between two creativity indicators should, in general, be stronger than that between creativity and an intelligence task. This aspect of construct validity can be evaluated through Multi-trait-Multi-method (MTMM) analysis; Campbell \& Fiske, 1959), which separates format or method (e.g., Likert-scale vs. performance test) from construct or trait (e.g., creativity vs. intelligence). The taxonomy we propose suggests factors that might be considered to conduct such analysis. Available findings help to address what might emerge from such analysis. In various studies, no substantial or high correlations have been found between measures of typical behavior (assessed with self-reports) and maximal cognitive effort (assessing abilities). The literature provides several examples of the little-to-no correlation between indicators (e.g., other's reports that are only weekly related with one another and unrelated with self-report (Richards et al., 1964; Taylor et al., 1963), creativity self-reports that are only weakly or not related with divergent thinking (Clapham, 2004). These weak correlations endorse the conclusion that measures of both behaviors assess distinct features.

We recommend 1) that creativity indicators should only bear the same label if they are highly related with one another and 2) a strict and careful use of labels and theoretical approaches that further describe the similarities and differences between indicators. We believe that this application would prevent further research results published under the same label. In sum, avoiding or carefully considering jingle fallacies would shed more light on creativity as a construct and its true nature. Besides, we recommend the use of divergent thinking tests. As measured with divergent thinking, the importance of originality is already made clear by the definition of creativity. Originality is a key attribute of creative products and can be measured best in a test situation and product/idea evaluation.

This guideline becomes even more important when so-called proxy variables are applied to gather indicators of creativity. As outlined above, measuring creativity suffers from 
jingle fallacies. This issue becomes more problematic when applied measures tap into different constructs. Measuring creativity with different constructs comes along with several drawbacks. However, we recognize the importance of such proxy measures for research as these measures might help enlarge the nomological net of creativity. Besides, using proxy variables for creativity is reasonable if the correlation between the proxy variable and the targeted aspect of creativity is very strong. For example, the assessment of creativity in the sense of self-reported preferences, based on openness measures has been justified by its positive relation with creativity (McCrae, 1987).

Taken together, we recommend assessing creativity based on validated multivariate measures. However, multivariate studies allow considering different measures and even proxy variables; thus, they are worth studying to shed more light on the nomological net of creativity and related constructs.

Although the taxonomy classifies different measures based on attributes, this does not strongly imply converging validity evidence across methods for assessing creativity. This result is due to the heterogeneity in conceptualizations and measurement approaches. In other words, at this stage, it is not possible to guarantee the validity of individual indicators to deliver valid measures of the cell within which they are placed. Therefore, we recommend a careful selection of creativity measures in line with the definition and the intended construct.

All things considered, we recommend the application of divergent thinking for assessing an individual's creativity. Although several psychometric problems must be considered, divergent thinking measures deliver results showing the smallest discrepancy between the construct definition and the scope of measures. Future research should address the remaining deficiencies of divergent thinking measures - many of which relate to the scoring of divergent thinking tasks (e.g., Reiter-Palmon et al., 2019). These deficiencies include the dependency between originality and fluency (Barbot, 2018; Forthmann et al., 
2018), stimulus dependencies (Barbot, 2018), and the relevancy of task instructions

(Nusbaum et al., 2014). These psychometric problems can be addressed by applying a broader range of tasks that are carefully and congruently instructed, analyzed, and scored (ReiterPalmon et al., 2019). Multivariate studies including such a broad task range (e.g., Runco Creativity Assessment Battery offers a selection of divergent thinking tasks also complemented by experimental approaches (3-D divergent thinking), self-reports, and even other's reports; Runco, 2011) can lead to better generalizability and hence foster the understanding of individual differences in creativity. Test development can also benefit from interdisciplinary work, including neuropsychological research (Benedek et al., 2019) and trials (such as the Multi-Trial Creative Ideation; Barbot, 2018).

In sum, although divergent thinking tests are the most widely applied indicators, there has generally been little progress in divergent thinking test development since the 1960s. In the following, we, therefore, describe perspectives for future creativity research, also including measurement development.

\section{Perspectives in Future Creativity Research}

There is a variety of prospects for creativity research. Here, we want to focus on two avenues: a) enlarging the nomological net of creativity and proximal constructs, and b) providing inspiration for novel creativity measures. First, creativity is studied for over a century, but there is still a surprising gap regarding multivariate studies exploring the validity and relationship between the measurement approaches, including related constructs. For example, only a few studies include achievement measures and self-reports of creative interest and divergent thinking measures of fluency and originality (e.g., Jauk et al., 2014).

Nevertheless, such extensive multivariate studies are necessary to improve our understanding of what creativity is and its relation to neighboring constructs/proxies. To better understand what creativity is, it is also worth studying if creativity should be further differentiated. This 
endeavor can be pursued by studying constructs that are supposedly highly similarmeasurement-wise and theoretically - to creativity. One example of such a construct is emotional creativity that should be further studied in relation to and differentiation from creativity (e.g., Ivcevic et al., 2007).

Concerning the second avenue, we need to acknowledge that for a long time creativity measures, especially divergent thinking tasks, have not improved much. However, recently new and interesting developments (e.g., implementing new technologies; Guegan et al., 2017), digitalization (e.g., digital CAT; Cseh et al., 2016) and scoring methods (Beaty \& Johnson, 2021; Reiter-Palmon et al., 2019) have been proposed. Still, a lot of currently applied divergent thinking tasks are often alterations of tasks that were originally suggested in the 1950s (e.g., Wilson et al., 1954). Despite the remarkable developments in several technologies, the literature on providing new approaches to pioneering ability tests is still sparse. Such technologies, for example, virtual realities, provide researchers with the opportunity to measure creative ability within a context that can be closer to real-life settings or contextualized fictional worlds than standard divergent thinking measures can provide. Virtual reality offers the chance to perform creatively and interact with other players within prespecified settings. We argue that behavior in gamified settings might be a promising avenue to capture novel aspects of creative potential. Apart from that, the data that can be derived from such settings might offer other intriguing ways of scorings that do not, or only partly, require human judges. Taken together, we believe that the development of divergent thinking settings (for individuals and groups) within such technologies could greatly further the understanding of creativity. 


\section{References}

Allport, G. W., Vernon, P. E., \& Lindzey, G. (1960). Study of values. Oxford, England: Houghton Mifflin.

Amabile, T. M. (1982). Social psychology of creativity: A consensual assessment technique. Journal of personality and social psychology, 43, 997-1013. http://dx.doi.org/10.1037/00223514.43.5.997

Amabile, T. M. (1996). Creativity in context: Update to the social psychology of creativity. Westview Press.

Amabile, T. M. (1985). Motivation and creativity: Effects of motivational orientation on creative writers. Journal of personality and social psychology, 48, 393-399. https://doi.org/10.1037/0022-3514.48.2.393

Antonietti, A., Colombo, B., \& Pizzingrilli, P. (2011). The WCR model of creativity. From concept to application. The Open Education Journal, 4, 80-89. https://doi.org/10.2174/1874920801104010080

Auzmendi, E., Villa, A., \& Abedi, J. (1996). Reliability and validity of a newly constructed multiplechoice creativity instrument. Creativity Research Journal, 9, 89-95. https://doi.org/10.1207/s15326934crj0901_8

Ayas, M. B., \& Sak, U. (2014). Objective measure of scientific creativity: Psychometric validity of the Creative Scientific Ability Test. Thinking Skills and Creativity, 13, 195-205. https://doi.org/10.1016/j.tsc.2014.06.001

Averill, J. R. (1999). Individual differences in emotional creativity: Structure and correlates. Journal of personality, 67, 331-371. https://doi.org/10.1111/1467-6494.00058

Averill, J. R., \& Thomas-Knowles, C. (1991). Emotional creativity. In K. T. Strongman (Ed.), International review of studies on emotion (Vol. 1, pp. 269-299). Wiley.

Baas, M., Koch, S., Nijstad, B. A., \& De Dreu, C. K. (2015). Conceiving creativity: The nature and consequences of laypeople's beliefs about the realization of creativity. Psychology of Aesthetics, Creativity, and the Arts, 9(3), 340-354. https://doi.org/10.1037/a0039420

Baer, J., Kaufman, J. C., \& Gentile, C. A. (2004). Extension of the consensual assessment technique to nonparallel creative products. Creativity research journal, 16, 113-117. https://doi.org/10.1207/s15326934crj1601_11

Baer, M., \& Oldham, G. R. (2006). The curvilinear relation between experienced creative time pressure and creativity: moderating effects of openness to experience and support for creativity. Journal of Applied Psychology, 91(4), 963-970. https://doi.org/10.1037/00219010.91.4.963

Baer, J., \& McKool, S. S. (2009). Assessing creativity using the consensual assessment technique. In C. Schreiner (Ed.), Handbook of research on assessment technologies, methods, and applications in higher education (pp. 65-77). IGI Global. https://doi.org/10.4018/978-1-60566-667-9.ch004

Baltzer, S. (1988). A validation study of a measure of musical creativity. Journal of Research in Music Education, 36, 232-249. https://doi.org/10.2307/3344876

Barbot, B., \& Lubart, T. (2012). Creative Thinking in Music: Its Nature and Assessment Through Musical Exploratory Behaviors. Psychology of Aesthetics, Creativity, and the Arts 6, 231242. https://doi.org/10.1037/a0027307

Barbot, B. (2018). The Dynamics of Creative Ideation: Introducing a New Assessment Paradigm. Frontiers in psychology, 9. https://doi.org/10.3389/fpsyg.2018.02529

Barbot, B., Hass, R. W., \& Reiter-Palmon, R. (2019). Creativity assessment in psychological research:(Re) setting the standards. Psychology of Aesthetics, Creativity, and the Arts, 13, 233-240. http://dx.doi.org/10.1037/aca0000233

Barron, F. (1955). The disposition toward originality. The Journal of Abnormal and Social Psychology, 51, 478-485. http://dx.doi.org/10.1037/h0048073

Barron, F. (1969). Creative person and creative process. New York: Holt, Rienhart \& Winston. 
Barron, F. (1955). The disposition toward originality. The Journal of Abnormal and Social Psychology, 51, 478-485. https://doi.org/10.1037/h0048073

Batey, M. (2012). The measurement of creativity: From definitional consensus to the introduction of a new heuristic framework. Creativity Research Journal, 24, 55-65. https://doi.org/10.1080/10400419.2012.649181

Batey, M., \& Furnham, A. (2008). The relationship between measures of creativity and schizotypy. Personality and Individual Differences, 45, 816-821. https://doi.org/10.1016/j.paid.2008.08.014

Beaty, R. E., \& Johnson, D. R. (2021). Automating creativity assessment with SemDis: An open platform for computing semantic distance. Behavior Research Methods, 53, 757-780. https://doi.org/10.3758/s13428-020-01453-w

Benedek, M., Christensen, A. P., Fink, A., \& Beaty, R. E. (2019). Creativity assessment in neuroscience research. Psychology of Aesthetics, Creativity, and the Arts, 13(2), 218-226. https://doi.org/10.1037/aca0000215

Berger, R. M., \& Guilford, J. P. (1969). Plot titles. Sheridan Psychological Services, Beverley Hills, CA: Sheridan Psychological Services.

Besemer, S. P., \& O'Quin, K. (1999). Confirming the three-factor creative product analysis matrix model in an American sample. Creativity Research Journal, 12(4), 287-296. https://doi.org/10.1207/s15326934crj1204_6

Besemer, S., \& O'Quin, K. (1986). Analyzing creative products: Refine- ment and test of a judging instrument. The Journal of Creative Behavior, 20(2), 115-126. https://doi.org/10.1002/j.21626057.1986.tb00426.x

Besemer, S. P., \& O'Quin, K. (1987). Creative product analysis: Testing a model by developing a judging instrument. Frontiers of Creativity Research: Beyond the Basics, 11(4), 367-389.

Bowden, E. M., Jung-Beeman, M., \& Beeman, M. (2003). One hundred forty-four compound remote associate problems: Short insight-like problems with one-word solutions. Behavioral Research, Methods, Instruments, and Computers, 35, 634-639.

Brittain, W. L., \& Beittel, K. R. (1964). A study of some tests of creativity in relationship to performances in the visual arts. Studies in Art Education, 2, 54-65. https://doi.org/10.2307/1319647

Buel, W. D. (1965). Biographical data and the identification of creative research personnel. Journal of Applied Psychology, 49, 318-321. https://doi.org/10.1037/h0022518

Bull, K. S., \& Davis, G. A. (1980). Evaluating creative potential using the statement of past creative activities. The Journal of Creative Behavior, 14, 249-257. https://doi.org/10.1002/j.2162$\underline{6057.1980 . t b 00256 . x}$

Byrd, R. E. (1986). Creativity and risk-taking. San Diego, CA: Pfeiffer International Publishers.

Carroll, J. B. (1993). Human cognitive abilities: A survey of factor-analytic studies. Cambridge: Cambridge University Press. https://doi.org/10.1080/00140139508925174

Carson, S. H., Peterson, J. B., \& Higgins, D. M. (2005). Reliability, validity, and factor structure of the creative achievement questionnaire. Creativity Research Journal, 17, 37-50. https://doi.org/10.1207/s15326934crj1701_4

Cattell, R. B. (1958). What is" objective" in" objective personality tests?". Journal of Counseling Psychology, 5, 285-289. https://doi.org10.1037/h0046268

Cattell, J. M. (1903). A statistical study of eminent men. Popular Science Monthly, 62, 359-377.

Cattell, J., Glascock, J., \& Washburn, M. F. (1918). Experiments on a possible test of aesthetic judgment of pictures. The American Journal of Psychology, 29, 333-336. https://doi.org/10.2307/1414125

Campbell, D. T., \& Fiske, D. W. (1959). Convergent and discriminant validation by the multitraitmultimethod matrix. Psychological bulletin, 56, 81-105. https://doi.org/10.1037/h0046016 
Cseh, G. M., Jeffries, K. K., Lochrie, M., Egglestone, P., \& Beattie, A. A. (2016). A DigitalCAT: A Fusion of Creativity Assessment Theory and HCI. Proceedings of the 30th International BCS Human Computer Interaction Conference: Companion Volume (p. 25). BCS Learning \& Development Ltd.

Cseh, G. M., \& Jeffries, K. K. (2019). A scattered CAT: A critical evaluation of the consensual assessment technique for creativity research. Psychology of Aesthetics, Creativity, and the Arts, 13(2), 159-166. https://doi.org/10.1037/aca0000220

Coffman, D. D. (1992). Measuring musical originality using information theory. Psychology of Music, 20, 154-161. https://doi.org/10.1177/0305735692202005

Davis, G. A. (1999). Barriers to creativity and creative attitudes. Encyclopedia of creativity, 1, 165174.

Chakrabarti, A. (2013). Understanding influences on engineering creativity and innovation: a biographical study of 12 outstanding engineering designers and innovators. International Journal of Design Creativity and Innovation, 1, 56-68. https://doi.org/10.1080/21650349.2013.754643

Chart, H., Grigorenko, E. L., \& Sternberg, R. J. (2008). Identification: The Aurora Battery. In J. A. Plucker \& C. M. Callahan (Eds.), Critical issues and practices in gifted education: What the research says (pp. 281-301). Waco, TX, US: Prufrock Press.

Charyton, C., \& Merrill, J. A. (2009). Assessing general creativity and creative engineering design in first year engineering students. Journal of engineering education, 98, 145-156. https://doi.org/10.1002/j.2168-9830.2009.tb01013.x

Chassell, L. M. (1916). Tests for originality. Journal of Educational Psychology, 7(6), 317-328.

Christensen, P. R., Guilford, J. P., Merrifield, P. R., \& Wilson, R. C. (1960). Alternate uses. Beverly Hills: Sheridan Psychological Services.

Christensen, P. R., Merrifield, P. R., \& Guilford, J. P. (1958). Consequences. Consulting Psychologists Press.

Chu, Y., \& MacGregor, J. N. (2011). Human performance on insight problem solving: A review. The Journal of Problem Solving, 3, 6-38. https://doi.org/10.7771/1932-6246.1094

Clapham, M. M. (2004). The convergent validity of the Torrance Tests of Creative Thinking and creativity interest inventories. Educational and Psychological Measurement, 64, 828-841. https://doi.org/10.1177/0013164404263883

Cleland, F. E. (1994). Young children's divergent movement ability: Study II. Journal of teaching in Physical Education, 13, 228-241. https://doi.org/10.1123/jtpe.13.3.228

Cohen, J. (1960). A coefficient of agreement for nominal scales. Educational and psychological measurement, 20, 37-46. https://doi.org/10.1177/001316446002000104

Connelly, B. S., \& Ones, D. S. (2010). An other perspective on personality: Meta-analytic integration of observers' accuracy and predictive validity. Psychological Bulletin, 136, 1092-1122. https://doi.org/10.1037/a0021212

Correia, C. M. (2014). Measuring creativity in the EU member states. Investigaciones regionales: Journal of Regional Research, 30, 7-26.

Cropley, D. H., \& Kaufman, J. C. (2012). Measuring functional creativity: Non-expert raters and the Creative Solution Diagnosis Scale. The Journal of Creative Behavior, 46, 119-137. https://doi.org/10.1002/jocb.9

Cropley, A. (2006). In praise of convergent thinking. Creativity research journal, 18, 391-404. https://doi.org/10.1207/s15326934crj1803_13

Cseh, G. M., Jeffries, K. K., Lochrie, M., Egglestone, P., \& Beattie, A. A. (2016). A DigitalCAT: A Fusion of Creativity Assessment Theory and HCI. In Proceedings of the 30th International BCS Human Computer Interaction Conference: Companion Volume (p. 25). BCS Learning \& Developement Ltd. 
Csikszentmihalyi, M., \& Getzels, J. W. (1970). Concern for discovery: An attitudinal component of creative production. Journal of Personality, 38, 91-105. https://doi.org/10.1111/j.14676494.1970.tb00639.x

Davis, G. A., \& Rimm, S. (1982). Group inventory for finding interests:(GIFFI) I and II: Instruments for identifying creative potential in the junior and senior high school. The Journal of Creative Behavior, 16, 50-57. https://doi.org/10.1002/j.2162-6057.1982.tb00321.x

Dewing, K., \& Hetherington, P. (1974). Anagram solving as a function of word imagery. Journal of Experimental Psychology, 102, 764-767. https://doi.org/10.1037/h0036339

Diedrich, J., Jauk, E., Silvia, P. J., Gredlein, J. M., Neubauer, A. C., \& Benedek, M. (2018). Assessment of real-life creativity: The Inventory of Creative Activities and Achievements (ICAA). Psychology of Aesthetics, Creativity, and the Arts, 12, 304-316. https://doi.org/10.1037/aca0000137

Dollinger, S. J. (2003). Need for uniqueness, need for cognition, and creativity. The Journal of Creative Behavior, 37, 99-116. https://doi.org/10.1002/j.2162-6057.2003.tb00828.x

Domino, G. (1994). Assessment of creativity using the ACL: A comparison of four scales. Creativity Research Journal, 7, 21-23. https://doi.org/10.1080/10400419409534506

Doolittle, J. H. (1989). The Creative Reasoning Test. Midwest Publications.

Dow, G. T., \& Mayer, R. E. (2004). Teaching students to solve insight problems: Evidence for domain specificity in creativity training. Creativity Research Journal, 16, 389-398. https://doi.org/10.1080/10400410409534550

Drevdahl, J. E. (1956). Factors of importance for creativity. Journal of Clinical Psychology, 12, 2126. https://doi.org/10.1002/1097-4679(195601)12:1<21::AID-JCLP2270120104>3.0.CO;2-S

Durmysheva, Y., \& Kozbelt, A. (2010). The creative approach questionnaire: Operationalizing Galenson's finder-seeker typology in a non-expert sample. The International Journal of Creativity \& Problem Solving, 20, 35-55.

French, J. W., Ekstrom, R. B., \& Price, L. A. (1963). Kit of reference tests for cognitive factors. Educational Testing Service.

Ekstrom, R. B., French, J. W., Harman, H., \& Derman, D. (1976). Kit of factor-referenced cognitive tests (rev. ed.). Educational Testing Service.

Epstein, R., Schmidt, S. M., \& Warfel, R. (2008). Measuring and training creativity competencies: Validation of a new test. Creativity Research Journal, 20, 7-12. https://doi.org/10.1080/10400410701839876

Erickson, C., Gantz, B. S., \& Stephenson, R. W. (1970). Logical and construct validation of a shortform biographical inventory predictor of scientific creativity. In Proceedings of the Annual Convention of the American Psychological Association. American Psychological Association.

Eysenck, H. J. (1996). The measurement of creativity. In M. A. Boden (Ed.), Dimensions of creativity (pp. 199-242). Cambridge, MA: MIT Press.

Feist, G. J. (1998). A meta-analysis of personality in scientific and artistic creativity. Personality and social psychology review, 2, 290-309. https://doi.org/10.1207/s15327957pspr0204_5

Feldhusen, J. F., Houtz, J. C., \& Ringenbach, S. (1972). The Purdue elementary problem-solving inventory. Psychological Reports, 31, 891-901. https://doi.org/10.2466/pr0.1972.31.3.891

Fillis, I., \& McAuley, A. (2000). Modeling and measuring creativity at the interface. Journal of Marketing Theory and Practice, 8, 8-17. https://doi.org/10.1080/10696679.2000.11501864

Finke, R. A. (1995). Creative insight and preinventive forms. In R. J. Sternberg \& J. E. Davidson (Eds.), The nature of insight (pp. 255-280). Cambridge, MA, US: The MIT Press.

Forgeard, M. J., \& Kaufman, J. C. (2016). Who cares about imagination, creativity, and innovation, and why? A review. Psychology of Aesthetics, Creativity, and the Arts, 10(3), 250-269. https://doi.org/10.1037/aca0000042 
Forthmann, B., Holling, H., Çelik, P., Storme, M., \& Lubart, T. (2017). Typing speed as a confounding variable and the measurement of quality in divergent thinking. Creativity Research Journal, 29, 257-269. https://doi.org/10.1080/10400419.2017.1360059

Forthmann, B., Jendryczko, D., Scharfen, J., Kleinkorres, R., Benedek, M., \& Holling, H., (2019). Creative ideation, broad retrieval ability, and processing speed: A confirmatory study of nested cognitive abilities. Intelligence, 75, 59-72. https://doi.org/10.1016/j.intell.2019.04.0

Forthmann, B., Szardenings, C., \& Holling, H. (2018). Understanding the confounding effect of fluency in divergent thinking scores: Revisiting average scores to quantify artifactual correlation. Psychology of Aesthetics, Creativity, and the Arts. https://doi.org/10.1037/aca0000196

Forthmann, B., Szardenings, C., \& Dumas, D. (2021). Testing equal odds in creativity research. Psychology of Aesthetics, Creativity, and the Arts, 15(2), 324-339. https://doi.org/10.1037/aca0000294

Foster, J. (1971). Creativity and the teacher. Macmillan.

Frederiksen, N., Evans, F. R., \& Ward, W. C. (1975). Development of provisional criteria for the study of scientific creativity. Gifted Child Quarterly, 19, 60-65. https://doi.org/10.1177/001698627501900110

French, J. W., Price, L. A., \& Ekstrom, R. B. (1963). Manual for kit of ref erence tests for cognitive factors. Educational Testing Service. https:// doi.org/10.21236/ad0410915.

Fricke, B. G. (1965). Opinion, attitude and interest survey handbook: A guide to personality and interest measurement. OAIS Testing Program.

Gibson, C., Folley, B. S., \& Park, S. (2009). Enhanced divergent thinking and creativity in musicians: A behavioral and near-infrared spectroscopy study. Brain and cognition, 69, 162169. https://doi.org/10.1016/j.bandc.2008.07.009

Gillian, J. E., Carpenter, B. O., \& Christensen, J. R. (1996). Gifted and Talented Evaluation Scales (GATES). Traducción Madrid: PSYMTE.

Giovannelli, F., Silingardi, D., Borgheresi, A., Feurra, M., Amati, G., Pizzorusso, T., ... \& Cincotta, M. (2010). Involvement of the parietal cortex in perceptual learning (Eureka effect): an interference approach using rTMS. Neuropsychologia, 48, 1807-1812. https://doi.org/10.1016/j.neuropsychologia.2010.02.031

Goldberg, L. R., Johnson, J. A., Eber, H. W., Hogan, R., Ashton, M. C., Cloninger, C. R., \& Gough, H. G. (2006). The international personality item pool and the future of public-domain personality measures. Journal of Research in personality, 40, 84-96. https://doi.org/10.1016/j.jrp.2005.08.007

Gorder, W. D. (1980). Divergent production abilities as constructs of musical creativity. Journal of Research in Music Education, 28, 34-42. https://doi.org/10.2307/3345051

Gough, H. G. (1975). A new scientific uses test and its relationship to creativity in research. The Journal of Creative Behavior, 9, 245-252. https://doi.org/10.1002/j.2162-6057.1975.tb00573.x

Gough, H. G. (1979). A creative personality scale for the adjective check list. Journal of personality and social psychology, 37, 1398-1405. https://doi.org/10.1037/0022-3514.37.8.1398

Gough, H. G. (1992). Assessment of creative potential in psychology and the development of a creative temperament scale for the CPI. In J. C. Rosen, \& P. McReynolds (Eds.), Advances in psychological assessment (pp. 225-257). Springer. https://doi.org/10.1007/978-1-4757-91013_8

Gough, H. G. (1976). Studying creativity by means of word association tests. Journal of Applied Psychology, 61, 348-353. http://dx.doi.org/10.1037/0021-9010.61.3.348

Gough, H. G., \& Heilbrun, A. B. (1983). The adjective check list. Consulting Psychologists Press.

Green, A. E., Cohen, M. S., Kim, J. U., \& Gray, J. R. (2012). An explicit cue improves creative analogical reasoning. Intelligence, 40, 598-603. https://doi.org/10.1016/j.intell.2012.08.005 
Gross, R. B., \& Marsh, M. (1970). An instrument for measuring creativity in young children: The Gross Geometric Forms. Developmental Psychology, 3, 267. https://doi.org/10.1037/h0029585

Guegan, J., Nelson, J., \& Lubart, T. (2017). The relationship between contextual cues in virtual environments and creative processes. Cyberpsychology, Behavior, and Social Networking, 20(3), 202-206. https://doi.org/10.1089/cyber.2016.0503

Guilford, J. P. (1947). Army Air Forces Aviation Psychology Program research reports. Printed classification tests: Report no. 5. U.S. Government Printing Office. https://doi.org/10.1037/14946-000

Guilford, J. P. (1986). Creative talents: Their nature, uses and development. Buffalo, NY: Bearly Limited.

Guilford, J. P. (1950). Creativity. American Psychologist, 5, 444-454. https://doi.org/10.1037/h0063487

Guilford, J. P. (1963). Guilford-Zimmerman Interest Inventory. Beverley Hills, CA: Sheridan Psychological Services.

Guilford, J. P. (1956). The structure of intellect. Psychological bulletin, 53, 267-293. https://doi.org/10.1037/h0040755

Guilford, J. P. (1967). The nature of human intelligence. New York, US: McGraw-Hill.

Guilford, J. P., Wilson, R. C., \& Christensen, P. R. (1952). A Factor-analytic Study of Creative Thinking: Administration of Tests and Analysis of Results. II. University of Southern California.

Hakstian, A. R., \& Cattell, R. B. (1975). CAB (comprehensive Ability Battery). Institute for Personality and Ability Testing.

Hall, W. B. (1972). A technique for assessing aesthetic predispositions: Mosaic construction test. The Journal of Creative Behavior, 6, 225-235. https://doi.org/10.1002/j.21626057.1972.tb00935.x

Hall, W. B., \& MacKinnin, D. W. (1969). Personality inventory correlates of creativity among architects. Journal of Applied Psychology, 53, 322-326. https://doi.org/10.1037/h0027811

Han, S. H., Yun, M. H., Kim, K. J., \& Kwahk, J. (2000). Evaluation of product usability: development and validation of usability dimensions and design elements based on empirical models. International Journal of Industrial Ergonomics, 26, 477-488. https://doi.org/10.1016/s0169-8141(00)00019-6

Harmon, L. R. (1963). The development of a criterion of scientific compe- tence. In C.W. Taylor and F. Barron (Eds.), Scientific creativity: Its recognition and development (pp. 44-52). John Wiley.

Harris, R. H., \& Simberg, A. L. (1959). AC test of creative ability. University of Chicago, industrial relations Center.

Hawthorne, G., Saggar, M., Quintin, E. M., Bott, N., Keinitz, E., Liu, N., Chien, Y., Hong, D., Royalty, A., \& Reiss, A. L. (2016). Designing a Creativity Assessment Tool for the TwentyFirst Century: Preliminary Results and Insights from Developing a Design-Thinking Based Assessment of Creative Capacity. In H. Plattner, C. Meinel, \& L. Leifer (Eds.), Design thinking research: Understanding innovation (pp. 111-123). Springer. https://doi.org/10.1007/978-3-319-19641-1_8

Helson, R. (1971). Women mathematicians and the creative personality. Journal of Consulting and Clinical Psychology, 36, 210-220. https://doi.org/10.1037/h0030728

Helson, R., \& Crutchfield, R. S. (1970). Mathematicians: The creative researcher and the average $\mathrm{PhD}$. Journal of consulting and clinical psychology, 34, 250-257. https://doi.org/10.1037/h0029003 
Hensel, N. H. (1973). The development, implementation, and evaluation of a creative dramatics program for kindergarten children (doctoral dissertation University of Georgia, 1973), Dissertation Abstracts International, 34, 4562A. University Microfilms No. 74-4816.

Hocevar, D. (1981). Measurement of creativity: Review and critique. Journal of Personality assessment, 45, 450-464. https://doi.org/10.1207/s15327752jpa4505_1

Hocevar, D. (1979, April). The development of the creative behavior inventory [Paper presentation]. The Annual Meeting of the Rocky Mountain Psychological Association.

Hofstee, W. K., De Raad, B., \& Goldberg, L. R. (1992). Integration of the big five and circumplex approaches to trait structure. Journal of personality and social psychology, 63, 146-163. https://doi.org/10.1037//0022-3514.63.1.146

Hogan, R., \& Hogan, J. (1992). Hogan Personality Inventory Manual (2nd ed.). Hogan Assessment Systems.

Holland, J. L., \& Nichols, R. C. (1964). Prediction of academic and extra-curricular achievement in college. Journal of Educational Psychology, 55, 55-65. https://doi.org/10.1037/h0047977

Holland, J. L., Fritzsche, B. A., \& Powell, A. B. (1997). The Self-directed Search (SDS): Technical Manual. Psychological Assessment Resources.

Horn, D., \& Salvendy, G. (2006). Consumer-based assessment of product creativity: A review and reappraisal. Human factors and ergonomics in manufacturing \& service industries, 16, 155175. https://doi.org/10.1002/hfm.20047

Houtz, J. C. (1985). Review of Thinking Creatively with Sounds and Words. Test critiques, 4, 666672.

Industrial Relations Center. (1959). AC Test of Creative Ability: Test administration manual. Chicago: Industrial Relations Center, University of Chicago.

Institute for Behavioral Research in Creativity. (1968). Alpha Biographical Inventory. Greensboro, North Carolina: Prediction Press.

Ivcevic, Z., Brackett, M. A., \& Mayer, J. D. (2007). Emotional intelligence and emotional creativity. Journal of personality, 75(2), 199-236. https://doi.org/10.1111/j.1467-6494.2007.00437.x

Ivcevic, Z., \& Mayer, J. D. (2009). Mapping dimensions of creativity in the life-space. Creativity Research Journal, 21(2-3), 152-165. https://doi.org/10.1080/10400410902855259

Jackson, D. N. (1994). French Jackson Personality Inventory-Revised manual. Sigma Assessment Systems.

Jauk, E., Benedek, M., \& Neubauer, A. C. (2014). The road to creative achievement: A latent variable model of ability and personality predictors. European journal of personality, 28, $95-$ 105. https://doi.org/10.1016/j.paid.2013.07.129

Jeffries, K. K. (2017). A CAT with caveats: is the Consensual Assessment Technique a reliable measure of graphic design creativity?. International Journal of Design Creativity and Innovation, 5, 16-28. https://doi.org/10.1080/21650349.2015.1084893

Jellen, H. G., \& Urban, K. K. (1989). Assessing creative potential world-wide: The first crosscultural application of the Test for Creative Thinking-Drawing Production (TCT-DP). Gifted Education International, 6, 78-86. https://doi.org/10.1177/026142948900600204

Johnson, D. L. (1979). Creativity checklist. Stoelting.

Johnson, D. L. (1979). Gifted and Talented Screening Form. Stoelting.

Johnson, J. A. (1994). Clarification of factor five with the help of the AB5C model. European Journal of Personality, 8, 311-334. https://doi.org/10.1002/per.2410080408

Kandler, C., Riemann, R., Angleitner, A., Spinath, F. M., Borkenau, P., \& Penke, L. (2016). The nature of creativity: The roles of genetic factors, personality traits, cognitive abilities, and environmental sources. Journal of Personality and Social Psychology, 111(2), 230-249. https://doi.org/10.1037/pspp0000087

Karwowski, M., Lebuda, I., \& Wiśniewska, E. (2018). Measuring creative self-efficacy and creative personal identity. The International Journal of Creativity \& Problem Solving, 28(1), 45-57. 
Kaufman, J. C. (2012). Counting the muses: development of the Kaufman domains of creativity scale (K-DOCS). Psychology of Aesthetics, Creativity, and the Arts, 6, 298-308. http://dx.doi.org/10.1037/a0029751

Kaufman, J. C., \& Baer, J. (2004). Sure, I'm creative—but not in mathematics!: Self-reported creativity in diverse domains. Empirical studies of the Arts, 22, 143-155. https://doi.org/10.2190/26hq-vhe8-gtln-bjjm

Kaufman, J. C., Cole, J. C., \& Baer, J. (2009). The construct of creativity: Structural model for selfreported creativity ratings. The Journal of Creative Behavior, 43(2), 119-134. https://doi.org/10.1002/j.2162-6057.2009.tb01310.x

Kaufman, J. C. (2019). Self-assessments of creativity: Not ideal, but better than you think. Psychology of aesthetics, creativity, and the arts, 13(2), 187-192. https://doi.org/10.1037/aca0000217

Kazdin, A. E., (2000). Encyclopedia of psychology. Washington, DC: American Psychological Association.

Khatena, J., \& Morse, D. T. (1994). Khatena-Morse Multitalent Perception Inventory: Scoring and Administration Guide: Norms-technical Manual. Scholastic Testing Service, Incorporated.

Khatena, J., \& Torrance, E. P. (1976). Khatena-Torrance creative perception inventory. Stoelting Company. https://doi.org/10.1037/t12018-000

Kim, K. H. (2006). Can we trust creativity tests? A review of the Torrance Tests of Creative Thinking (TTCT). Creativity research journal, 18, 3-14. https://doi.org/10.1207/s15326934crj1801_2

Kirschenbaum, R. J. (1989). Understanding the creative activity of students: Including an instruction manual for the creative behavior inventory. Creative Learning Press.

Kirschenbaum, R. J. (1998). The creativity classification system: An assessment theory. Roeper Review, 21, 20-26. https://doi.org/10.1080/02783199809553921

Kiratli, N., Rozemeijer, F., Hilken, T., de Ruyter, K., \& de Jong, A. (2016). Climate setting in sourcing teams: Developing a measurement scale for team creativity climate. Journal of Purchasing and Supply Management, 22, 196-204. https://doi.org/10.1016/j.pursup.2016.04.006

Knoblich, G., Ohlsson, S., Haider, H., \& Rhenius, D. (1999). Constraint relaxation and chunk decomposition in insight problem solving. Journal of Experimental Psychology: Learning, Memory, and Cognition, 25, 1534-1555. https://doi.org/10.1037//0278-7393.25.6.1534

Köhler, W. (1967). Gestalt psychology. Psychological Research, 31, 18-80. https://doi.org/10.1007/BF00422382

Kumar, V. K., \& Holman, E. R. (1989). Creativity styles questionnaire. Unpublished instrument.

Lawshe, C. H., \& Harris, D. H. (1960). Manual of Instructions: Purdue Creativity Test. Lafayette, Indiana, Purdue Research Foundation.

Lees-Haley, P. R. (1978). Creative behavior inventory. Huntsville, Alabama: Basic Research, Inc..

Long, H. (2014). An empirical review of research methodologies and methods in creativity studies (2003-2012). Creativity Research Journal, 26, 427-438.

Long, H., \& Plucker, J. (2015). Assessing creative thinking: Practical applications. In R. Wegerif, L. Li, \& J. Kaufman (Eds.), The Routledge international handbook of research on teaching thinking (pp. 315-329). Routledge. https://doi.org/10.1080/10400419.2014.961781

Long, H., Plucker, J. A., Yu, Q., Ding, Y., \& Kaufman, J. C. (2014). Research productivity and performance of journals in the creativity sciences: A bibliometric analysis. Creativity Research Journal, 26(3), 353-360. https://doi.org/10.1080/10400419.2014.929425

Lubart, T. I., Besançon, M., \& Barbot, B. (2011). Evaluation du potentiel créatif (EPoC). Paris, France: Editions Hogrefe.

Lubart, T. I. (1994). Product-centered self-evaluation and the creative process. Unpublished doctoral dissertation, Yale University, New Haven, CT. 
Luo, J., \& Niki, K. (2003). Function of hippocampus in "insight" of problem solving. Hippocampus, 13, 316-323. https://doi.org/10.1002/hipo.10069

MacGregor, J. N., \& Cunningham, J. B. (2008). Rebus puzzles as insight problems. Behavior Research Methods, 40, 263-268. https://doi.org/10.3758/brm.40.1.263

Madjar, N., \& Ortiz-Walters, R. (2008). Customers as contributors and reliable evaluators of creativity in the service industry. Journal of Organizational Behavior: The International Journal of Industrial, Occupational and Organizational Psychology and Behavior, 29(7), 949-966. https://doi.org/10.1002/job.522

Martin, J., \& Cox, D. (2016). Positioning Steve Nash: A Theory-Driven, Social Psychological, and Biographical Case Study of Creativity in Sport. The Sport Psychologist, 30, 388-398. https://doi.org/10.1123/tsp.2016-0002

Martindale, C., Hines, D., Mitchell, L., \& Covello, E. (1984). EEG alpha asymmetry and creativity. Personality and Individual Differences, 5, 77-86. https://doi.org/10.1016/0191$\underline{8869(84) 90140-5}$

Mayer, R. E. (1995). Structural analysis of science prose: Can we increase problem-solving performance?. ACM SIGDOC Asterisk Journal of Computer Documentation, 19, 3-25. https://doi.org/10.1145/216708.216709

Mayer, R. E. (1999). Fifty years of creativity research. In R. J. Sternberg (Ed.), Handbook of creativity, 449 - 460. New York, NY: Cambridge University Press. https://doi.org/10.1017/cbo9780511807916.024

McCrae, R. R. (1987). Creativity, divergent thinking, and openness to experience. Journal of personality and social psychology, 52, 1258. https://doi.org/10.1037//0022-3514.52.6.1258

Mednick, S. A., \& Mednick, M. T. (1967). Examiner's manual, Remote Associates Test: College and adult forms 1 and 2. Houghton Mifflin.

Meeker, M. (1978). Measuring creativity from the child's point of view. The Journal of Creative Behavior, 12, 52-62. https://doi.org/10.1002/j.2162-6057.1978.tb00159.x

Michael, W. B., \& Colson, K. R. (1979). The development and validation of a life experience inventory for the identification of creative electrical engineers. Educational and Psychological Measurement, 39, 463-470. https://doi.org/10.1177/001316447903900228

Miller, A. L. (2009). Cognitive processes associated with creativity: Scale development and validation (Doctoral dissertation, Ball State University).

Mumford, M. D., \& Gustafson, S. B. (1988). Creativity syndrome: Integration, application, and innovation. Psychological Bulletin, 103, 27-43. https://doi.org/10.1037//0033-2909.103.1.27

$\mathrm{Ng}, \mathrm{T}$. W., \& Feldman, D. C. (2012). A comparison of self-ratings and non-self-report measures of employee creativity. Human Relations, 65(8), 1021-1047. https://doi.org/10.1177/0018726712446015

Niu, W., \& Sternberg, R. J. (2001). Cultural influences on artistic creativity and its evaluation. International journal of psychology, 36, 225-241. https://doi.org/10.1080/00207590143000036

Novick, L. R., \& Sherman, S. J. (2003). On the nature of insight solutions: Evidence from skill differences in anagram solution. The Quarterly Journal of Experimental Psychology Section A, 56, 351-382. https://doi.org/10.1080/02724980244000288

Nusbaum, E. C., Silvia, P. J., \& Beaty, R. E. (2014). Ready, set, create: What instructing people to "be creative" reveals about the meaning and mechanisms of divergent thinking. Psychology of Aesthetics, Creativity, and the Arts, 8, 423-432. https://doi.org/10.1037/a0036549

O'Neil, H. F., Abedi, J., \& Spielberger, C. D. (1994). The measurement and teaching of creativity. In H. F. Jr. O'Neil \& M. Drillings (Eds.), Motivation: Theory and research (pp. 245-263). Routledge. 
O'Quin, K., \& Besemer, S. P. (1989). The development, reliability, and validity of the revised creative product semantic scale. Creativity Research Journal, 2, 267-278. https://doi.org/10.1080/10400418909534323

Owens, W. A. (1960). The Owens' Creativity Test for Machine Design. Iowa State University Press.

Owens, W. A., Schumacher, C. F., \& Clark, J. B. (1957). The measurement of creativity in machine design. Journal of Applied Psychology, 41, 297-302. https://doi.org/10.1037/h0040668

Plattner, H., Meinel, C., \& Leifer, L. (Eds.). (2015). Design thinking research: Making design thinking foundational. Springer. doi:10.1007/978-3-642-21643-5

Plucker, J. A., \& Makel, M. C. (2010). Assessment of creativity. In J. C. Kaufman \& R. J. Sternberg (Eds.), The Cambridge handbook of crea- tivity (pp. 48-73). Cambridge University Press. https://doi.org/10.1017/CBO9780511763205.005

Polya, G. (1945). How to solve it: A new aspect of mathematical model. Princeton, New Jersey: Princeton university press. https://doi.org/10.2307/2306109

Prabhakaran, R., Green, A. E., \& Gray, J. R. (2014). Thin slices of creativity: Using single-word utterances to assess creative cognition. Behavior research methods, 46, 641-659. https://doi.org/10.3758/s13428-013-0401-7

Pringle, A., \& Sowden, P. T. (2017). The Mode Shifting Index (MSI): A new measure of the creative thinking skill of shifting between associative and analytic thinking. Thinking Skills and Creativity, 23, 17-28. https://doi.org/10.1016/j.tsc.2016.10.010

Raudsepp, E. (1981). How creative are you?. Perigee.

Reid, J. B., King, F. J., \& Wickwire, P. (1959). Cognitive and other personality characteristics of creative children. Psychological Reports, 5, 729-737. https://doi.org/10.2466/pr0.1959.5.3.729

Reisman, F., Keiser, L., \& Otti, O. (2016). Development, use and implications of diagnostic creativity assessment app, RDCA-Reisman Diagnostic Creativity Assessment. Creativity Research Journal, 28(2), 177-187. https://doi.org/10.1080/10400419.2016.1162643

Reiter-Palmon, R., Forthmann, B., \& Barbot, B. (2019). Scoring divergent thinking tests: A review and systematic framework. Psychology of Aesthetics, Creativity, and the Arts, 13(2), 144-152. https://doi.org/10.1037/aca0000227

Renzulli, J. S., Smith, L. H., White, A. J., Callahan, C. M., Hartman, R. K., \& Westberg, K. L. (2002). Scales for rating the behavioral characteristics of superior students. Technical and administration manual. Creative Learning Press, Inc., PO Box 320, Mansfield, CT 06250.

Renzulli, J. S., \& Reis, S. M. (1981). Student product assessment form. Mansfield Center, CT: Creative Learning Press. Retrieved from: http://teachers.renzullilearning.com/downloads/SPAF.pdf.

Rhodes, M. (1961). An analysis of creativity. The Phi Delta Kappan, 42, 305-310.

Richards Jr, J. M., Cline, V. B., \& Needham, W. E. (1964). Creativity tests and teacher and self judgments of originality. The Journal of Experimental Education, 32, 281-285. https://doi.org/10.1080/00220973.1964.11010832

Richards, R., Kinney, D. K., Benet, M., \& Merzel, A. P. (1988). Assessing everyday creativity: Characteristics of the Lifetime Creativity Scales and validation with three large samples. Journal of Personality and Social Psychology, 54(3), 476-485. https://doi.org/10.1037/00223514.54.3.476

Richardson, C. P., \& Saffle, M. (1983). Creativity research in music education: A review. Bulletin of the Council for Research in Music Education, 74, 1-21. https://doi.org/10.1177\%2F8755123308322280

Rimm, S. B. (1980). Group inventory for finding creative talent (GIFT). Watertown, WI: Educational Assessment Service.

Rimm, S. B. (1983). PRIDE: Preschool and kindergarten interest descriptor. Educational Assessment Service. 
Robitzsch, A., \& Steinfeld, J. (2018). Item response models for human ratings: Overview, estimation methods, and implementation in R. Psychological Test and Assessment Modeling, 60(1), 101138.

Roe, A. (1951). A psychological study of eminent biologists. Psychological Monographs: general and applied, 65, i-68. ttps://doi.org/10.1037/h0093639

Rogaten, J., \& Moneta, G. B. (2015). Development and validation of the short use of creative cognition scale in studying. Educational Psychology, 35(3), 294-314. https://doi.org/10.1080/01443410.2013.857011

Rookey, T. J. (1971). The Pennsylvania assessment of creative tendency: Norms-technical manual. Pennsylvania: Pennsylvania Department of Education.

Runco, M. A. (1989). Parents' and teachers' ratings of the creativity of children. Journal of Social Behavior and Personality, 4, 73.

Runco, M. A., \& Jaeger, G. J. (2012). The standard definition of creativity. Creativity Research Journal, 24, 92-96. https://doi.org/10.1080/10400419.2012.650092

Runco, M. A., Millar, G., Acar, S., \& Cramond, B. (2010). Torrance tests of creative thinking as predictors of personal and public achievement: A fifty-year follow-up. Creativity Research Journal, 22, 361-368. https://doi.org/10.1080/10400419.2010.523393

Runco, M. A., Plucker, J. A., \& Lim, W. (2001). Development and psychometric integrity of a measure of ideational behavior. Creativity Research Journal, 13, 393-400. https://doi.org/10.1207/s15326934crj1334_16

Runco Creativity Assessment Battery (rCAB). (2011). Creativity Testing Services (CTS). Retrieved fromhttp://creativitytestingservices.com/

Rusch, R. R., Denny, D. A., \& Ives, S. (1964). The development of a test of creativity in the dramatic arts: a pilot study. The Journal of Educational Research, 57, 250-254. https://doi.org/10.1080/00220671.1964.10883073

Said-Metwaly, S., Van den Noortgate, W., \& Kyndt, E. (2017). Approaches to measuring creativity: A systematic literature review. Creativity. Theories-Research-Applications, 4(2), 238-275. https://doi.org/10.1515/ctra-2017-0013

Schack, G. D. (1989). Self-efficacy as a mediator in the creative productivity of gifted children. Journal for the Education of the Gifted, 12, 231-249. https://doi.org/10.1177/016235328901200306

Schaefer, C. E., \& Anastasi, A. (1968). A biographical inventory for identifying creativity in adolescent boys. Journal of Applied Psychology, 52, 42-48. https://doi.org/10.1037/h0025328

Schaefer, C. E., \& Bridges, C. I. (1970). Development of a creativity attitude survey for children. Perceptual and motor skills, 31, 861-862. https://doi.org/10.2466/pms.1970.31.3.861

Schultz, C. B., \& Skager, R. W. (1963). Relationship of an independent activities questionnaire to performance during high school. ETS Research Report Series, 1963(1), i-19. https://doi.org/10.1002/j.2333-8504.1963.tb00310.x

Shaw, G. A., \& Conway, M. (1990). Individual differences in nonconscious processing: The role of creativity. Personality and individual differences, 11, 407-418. https://doi.org/10.1016/0191$\underline{\text { 8869(90)90224-f }}$

Sheth, B. R., Sandkühler, S., \& Bhattacharya, J. (2009). Posterior beta and anterior gamma oscillations predict cognitive insight. Journal of Cognitive Neuroscience, 21, 1269-1279. https://doi.org/10.1162/jocn.2009.21069

Siegel, L. (1956). A biographical inventory for students: I. Construction and standardization of the instrument. Journal of Applied Psychology, 40, 5-10. https://doi.org/10.1037/h0040589

Silvia, P. J., Martin, C., \& Nusbaum, E. C. (2009). A snapshot of creativity: Evaluating a quick and simple method for assessing divergent thinking. Thinking Skills and Creativity, 4, 79-85. https://doi.org/10.1016/j.tsc.2009.06.005 
Silvia, P. J., Wigert, B., Reiter-Palmon, R., \& Kaufman, J. C. (2012). Assessing creativity with selfreport scales: A review and empirical evaluation. Psychology of Aesthetics, Creativity, and the Arts, 6(1), 19-34. https://doi.org/10.1037/a0024071

Silvia, P. J., Beaty, R. E., \& Nusbaum, E. C. (2013). Verbal fluency and creativity: General and specific contributions of broad retrieval ability $(\mathrm{Gr})$ factors to divergent thinking. Intelligence, 41(5), 328-340. https://doi.org/10.1016/j.intell.2013.05.004

Simonton, D. K. (1999). Creativity from a historiometric perspective. In R.J. Sternberg (Ed.), Handbook of creativity (pp. 116-133). Cambridge Unviersity Press.

Skager, R. W., Schultz, C. B., \& Klein, S. P. (1965). Quality and quantity of accomplishments as measures of creativity. Journal of Educational Psychology, 56, 31-39. https://doi.org/10.1037/h0021901

Slahova, A., Savvina, J., Cacka, M., \& Volonte, I. (2007). Creative activity in conception of sustainable development education. International Journal of Sustainability in Higher Education, 8(2), 142-154. https://doi.org/10.1108/14676370710726616

Snyder, H. T., Hammond, J. A., Grohman, M. G., \& Katz-Buonincontro, J. (2019). Creativity measurement in undergraduate students from 1984-2013: A systematic review. Psychology of Aesthetics, Creativity, and the Arts, 13(2), 133-143. https://doi.org/10.1037/aca0000228

Sprugnoli, G., Rossi, S., Emmerdorfer, A., Rossi, A., Liew, S. L., Tatti, E., .. \& Santarnecchi, E. (2017). Neural correlates of Eureka moment. Intelligence, 62, 99-118. https://doi.org/10.1016/j.intell.2017.03.004

Starkweather, E. K. (1971). Creativity research instruments designed for use with preschool children. The Journal of Creative Behavior, 5, 245-255. https://doi.org/10.1002/j.21626057.1971.tb00895.x

Starkweather, E. K. (1974). Starkweather originality test for young children. Oklahoma State University, Stillwater, Research Foundation.

Sternberg, R. J. (2012). The assessment of creativity: An investment-based approach. Creativity research journal, 24, 3-12. https://doi.org/10.1080/10400419.2012.652925

Stricker, L. J., Rock, D. A., \& Bennett, R. E. (2001). Sex and ethnic-group differences on accomplishments measures. Applied Measurement in Education, 14, 205-218. https://doi.org/10.1207/s15324818ame1403_1

Tagiuri, R. (1960). Movement as a cue in person perception. In H. P. David \& J. C. Brengelmann (Eds.), Perspectives in personality research (pp. 175-195). Springer. https://doi.org/10.1007/978-3-662-39598-1_9

Taylor, C. W., Smith, W. R., \& Ghiselin, B. (1963). The creative and other contributions of one sample of research scientists. In Scientific creativity: its recognition and development. (p. 6381). New York: Wiley.

Taylor, I. A., \& Fish, T. A. (1979). The Creative Behaviour Disposition Scale: A Canadian validation. Canadian Journal of Behavioural Science/Revue canadienne des sciences du comportement, 11, 95-97. https://doi.org/10.1037/h0081577

Taylor, I. A., \& Sandler, B. E. (1972). Use of a creative product inventory for evaluating products of chemists. Proceedings of the Annual Convention of the American Psychological Association, 7(Pt. 1), 311-312.

Taylor, I. A. (1975). An emerging view of creative actions. In I. A. Taylor\& J. W. Getzels (Eds.), Perspectives in creativity (pp. 297-325). Chicago: Aldine.

Taylor, I. A., Sutton, D., \& Haworth, S. (1974). The measurement of creative transactualization: A scale to measure behavioral dispositions to creativity. Journal of Creative Behavior, 8, 114115. https://doi.org/10.1002/j.2162-6057.1974.tb01118.x

Thorndike, E. L. (1904). An introduction to the theory of mental and social measurements. Teachers College, Columbia University. 
Tierney, P., \& Farmer, S. M. (2002). Creative self-efficacy: Its potential antecedents and relationship to creative performance. Academy of Management journal, 45, 1137-1148. https://doi.org/10.2307/3069429

Tierney, P., Farmer, S. M., \& Graen, G. B. (1999). An examination of leadership and employee creativity: The relevance of traits and relationships. Personnel psychology, 52, 591-620. https://doi.org/10.1111/j.1744-6570.1999.tb00173.x

Torrance, E. P. (1975). Assessing children, teachers, and parents against the ideal child criterion. Gifted Child Quarterly, 19, 130-139. https://doi.org/10.1177/001698627501900220

Torrance,E. P. (1962). Guiding Creative Talent. Prentice-Hall, Inc. https:// doi.org/10.1037/13134$\underline{000}$

Torrance, E. P. (1969a). Creativity. What Research Says to the Teacher, Series, (28) No (pp. 1-36). ERIC Clearinghouse.

Torrance, E. P. (1969b). Prediction of adult creative achievement among high school seniors. Gifted Child Quarterly, 13(4), 223-229. https://doi.org/10.1177/001698626901300401

Torrance, E. P. (1966). The Torrance Tests of Creative Thinking-Norms, Technical Manual Research Edition-Verbal Tests, Forms A and B-Figural Tests, Forms A and B. Princeton, NJ: Personnel Press.

Torrance, E. P., \& Gibbs, S. (1977). Administration, Scoring, and Norms Manual, Thinking Creatively in Action and Movement. Department of Educational Psychology, University of Georgia.

Torrance, E. P., Khatena, J., \& Cunnington, B. F. (1973). Thinking Creatively with Sounds and Words: Sounds and Images; Onomatopoeia and Images. Personnel Press/Ginn.

Vallée-Tourangeau, F. (Ed.). (2018). Insight: on the origins of new ideas. Routledge. https://doi.org/10.4324/9781315268118

Vincent-Lancrin, S. (2017). Future learning skills in a global context: from discourse to practice. Retrieved from: http://docplayer.net/51475061-Future-learning-skills-in-a-global-contextfrom-discourse-to-practice.html. [15-7-2019]

Wallach, M. A., \& Kogan, N. (1965). Modes of thinking in young children: A study of the creativityintelligence distinction. Oxford, England: Holt, Rinehart \& Winston.

Wallen, N. E., \& Stevenson, G. M. (1960). Stability and correlates of judged creativity in fifth grade writings. Journal of Educational Psychology, 51, 273-276. https://doi.org/10.1037/h0045933

Ward, W. C., \& Cox, P. W. (1974). A field study of nonverbal creativity. Journal of personality, 42, 202-219. https://doi.org/10.1111/j.1467-6494.1974.tb00670.x

Webster, P. R. (1994). Measure of Creative Thinking in Music:(MCTM): Administrative Guidelines. Peter Webster.

Wechsler, S. M., Vendramini, C. M. M., \& Oakland, T. (2012). Thinking and creative styles: A validity study. Creativity Research Journal, 24, 235-242. https://doi.org/10.1080/10400419.2012.677359

Weisberg, R. W. (1988). Problem solving and creativity. In R. J. Sternberg (Ed.), The nature of creativity: Contemporary psychological perspectives (pp. 148-176). Cambridge University Press.

Weiss, S., \& Roberts, R. D. (2018). Using anchoring vignettes to adjust self-reported personality: A comparison between countries. Frontiers in Psychology, 9, 325. https://doi.org/10.3389/fpsyg.2018.00325

Weiss, S., Steger, D., Kaur, Y., Hildebrandt, A., Schroeders, U., \& Wilhelm, O. (2021). On the trail of creativity: Dimensionality of diver- gent thinking and its relation with cognitive abilities, personality, and insight. European Journal of Personality, 35(3), 291-314. https://doi.org/10.1002/per.2288

Welsh, G. S., \& Barron, F. (1959). Barron-Welsh art scale. Consulting Psychologists Press. 
White, A., Shen, F., \& Smith, B. L. (2002). Judging advertising creativity using the creative product semantic scale. The Journal of Creative Behavior, 36, 241-253. https://doi.org/10.1002/j.2162-6057.2002.tb01067.x

Williams, F. E. (1993). Creativity Assessment Packet: CAP. Pro-Ed.

Wilson, R. C., Guilford, J. P., Christensen, P. R., \& Lewis, D. J. (1954). A factor-analytic study of creative-thinking abilities. Psychometrika, 19, 297-311. https://doi.org/10.1007/bf02289230

Yamamoto, K. (1964). Experimental Scoring Manuals for Minnesota Tests of Creative Thinking and Writing. Kent, OH: Bureau of Educational Research, Kent State University.

Zhang, X., \& Bartol, K. M. (2010). Linking empowering leadership and employee creativity: The influence of psychological empowerment, intrinsic motivation, and creative process engagement. Academy of management journal, 53(1), 107-128. https://doi.org/10.5465/amj.2010.48037118

Zhou, J., \& George, J. M. (2001). When job dissatisfaction leads to creativity: Encouraging the expression of voice. Academy of Management journal, 44(4), 682-696.

https://doi.org/10.5465/3069410 